\title{
Revitalização do Conjunto das Oficinas Porto Novo - Além Paraíba, MG
}

+ Complexo de Uso Misto

Letícia Almeida Cortat de Paula 


\section{LOCALIZAÇÃO}
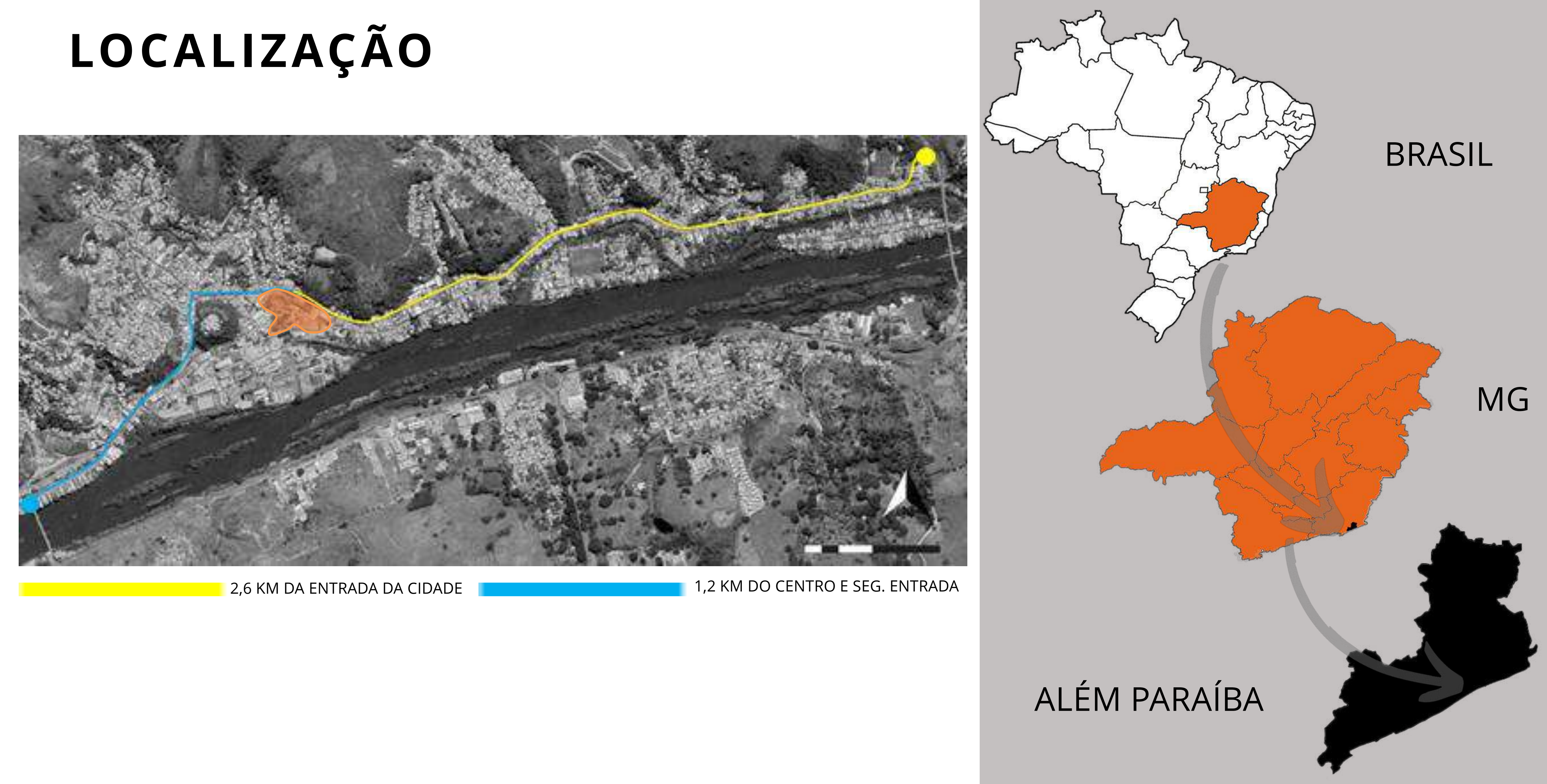


\section{REVITALIZAÇÃO}

Revitalização é uma reestruturação com o intuito de trazer vida em um objeto arquitetônico e/ou urbanístico que se encontra em estado de degradação. Podendo atribuir novo usos ou não. 


\section{O que é?}

Criação de um complexo de uso misto

- Mercado Municipal

- Secretaria de Cultura

- Memorial

- Parada de trem

\section{Para quem?}

- Habitantes do município e região

- Produtores do município e região

- Setor Público 


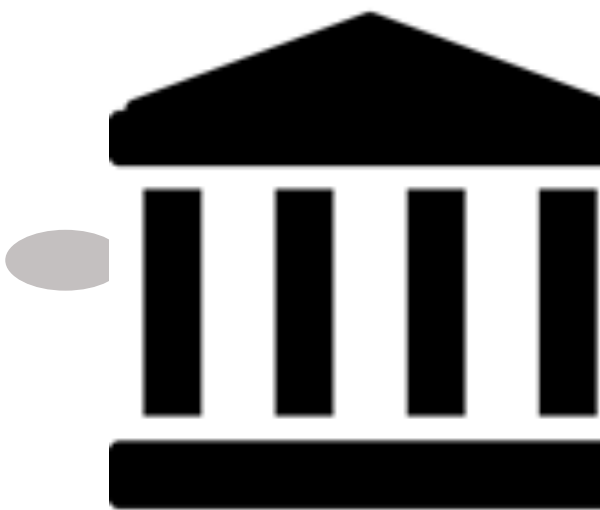

VALOR HISTÓRICO

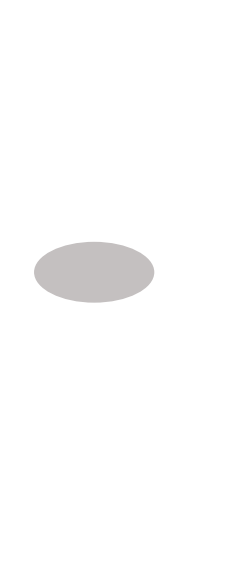

PERTENCIMENTO

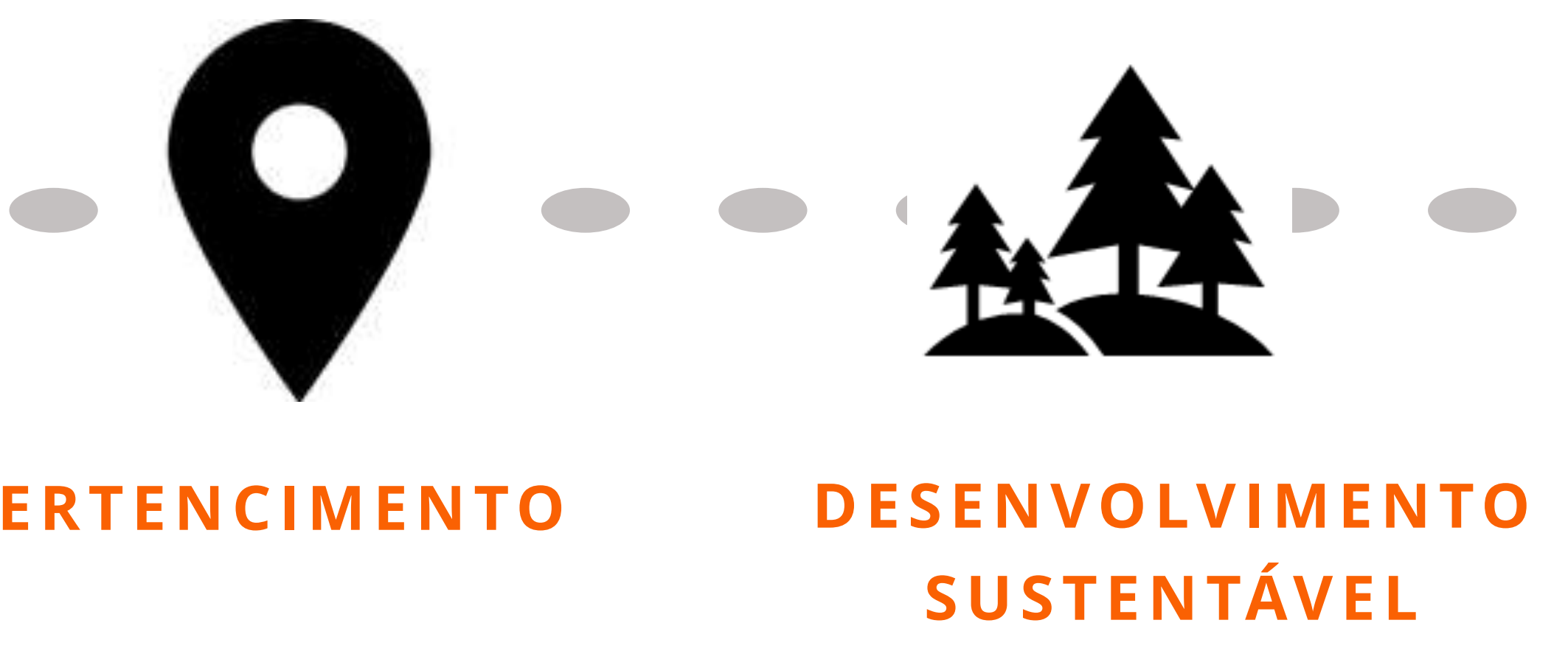

VALORIZAÇÃO REGIONAL 


\section{O CONJUNTO}

I NAUGURAÇÃO Ano: 1880

ÁREA

Aprox. $=22.263 \mathrm{~m}^{2}$

COMPOSTO

Rotunda

Escritório

Diversos galpões

$\mathrm{RH}$

Casa de Energia
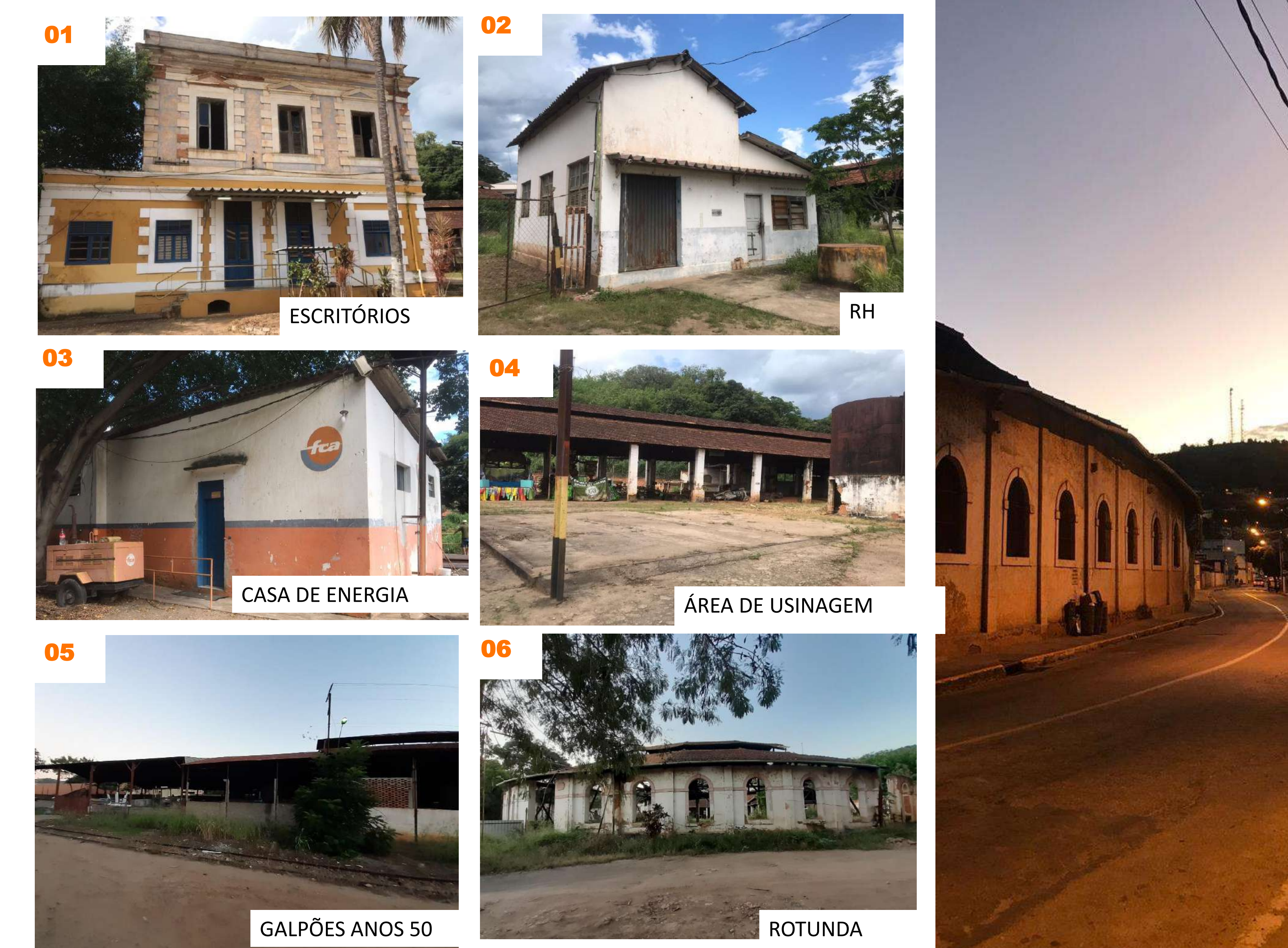


\section{CARACTERIZAÇÃO}

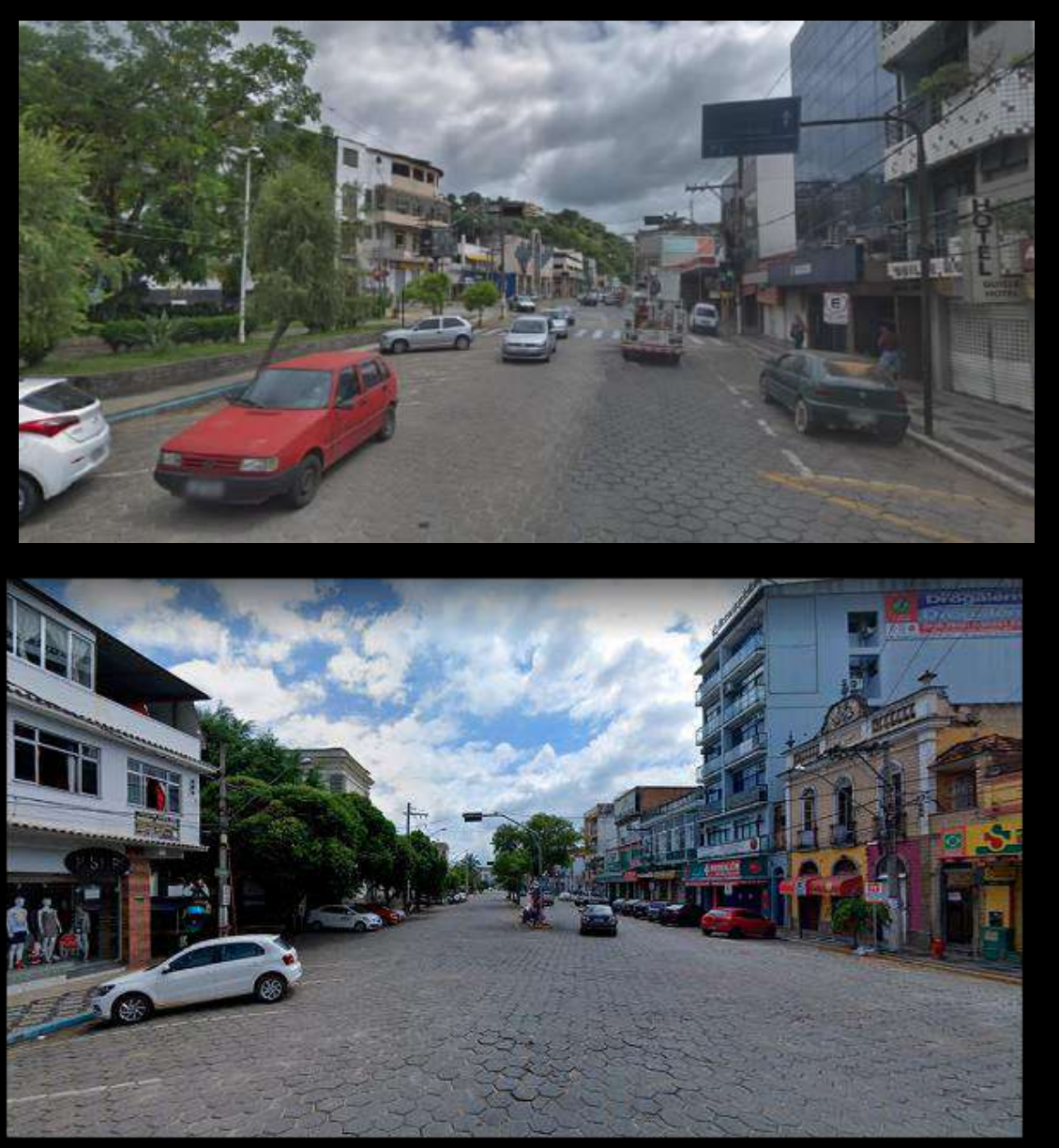

CENTRO COMERCIAL

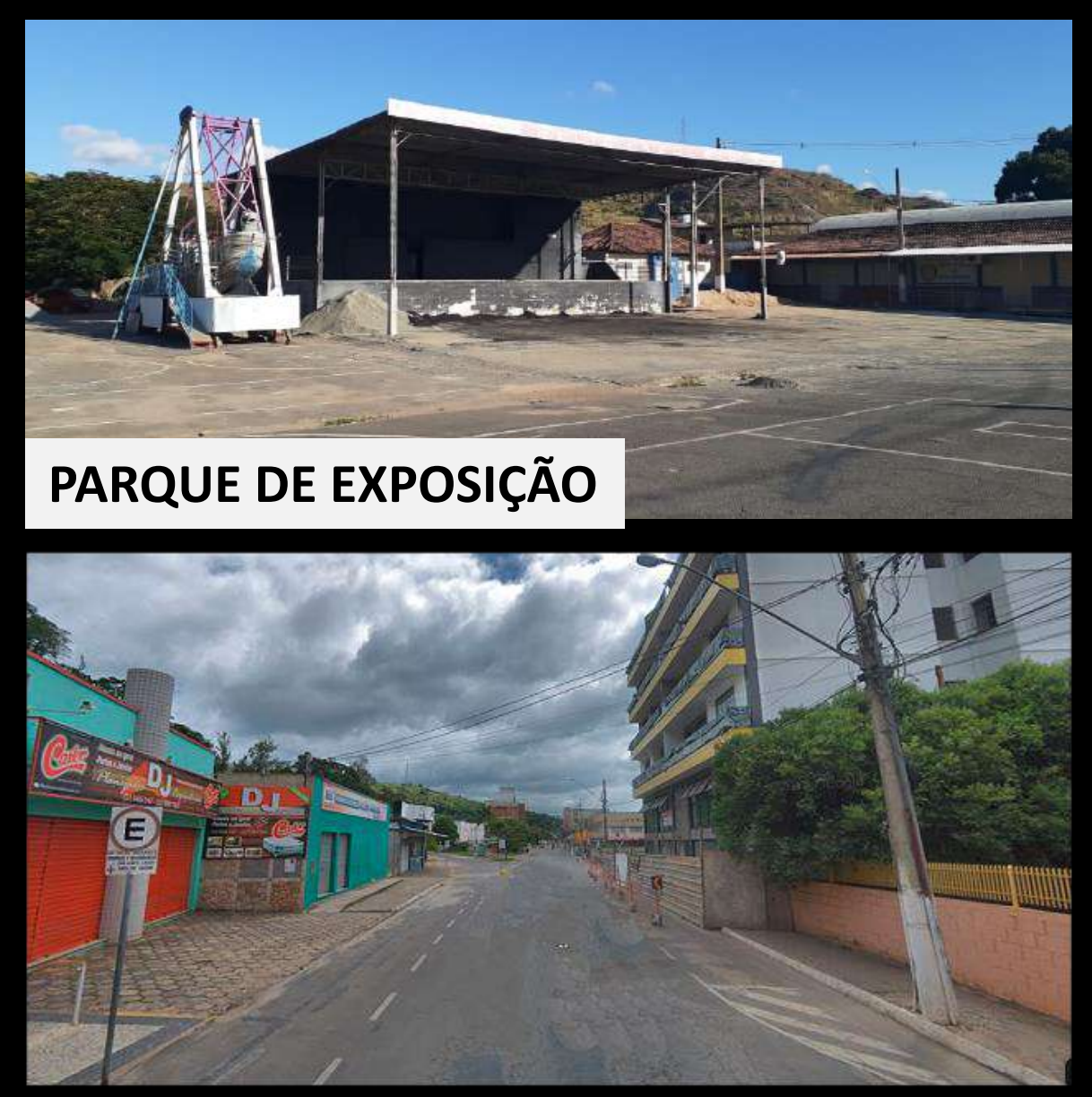

ILHA DO LAZARETO
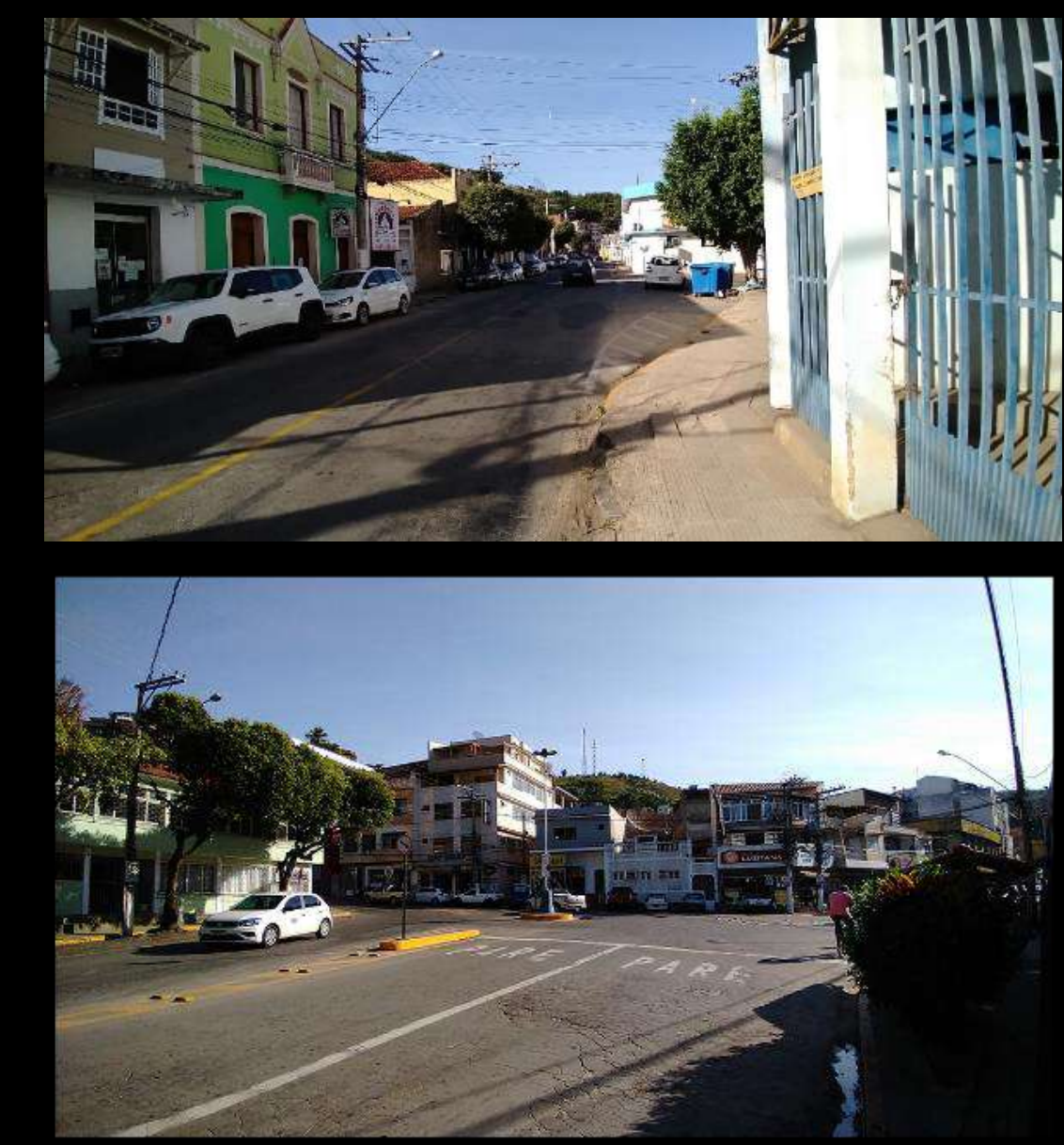

VILA LAROCA
TERRENO

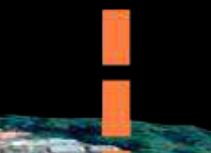




\section{O CONJUNTO}
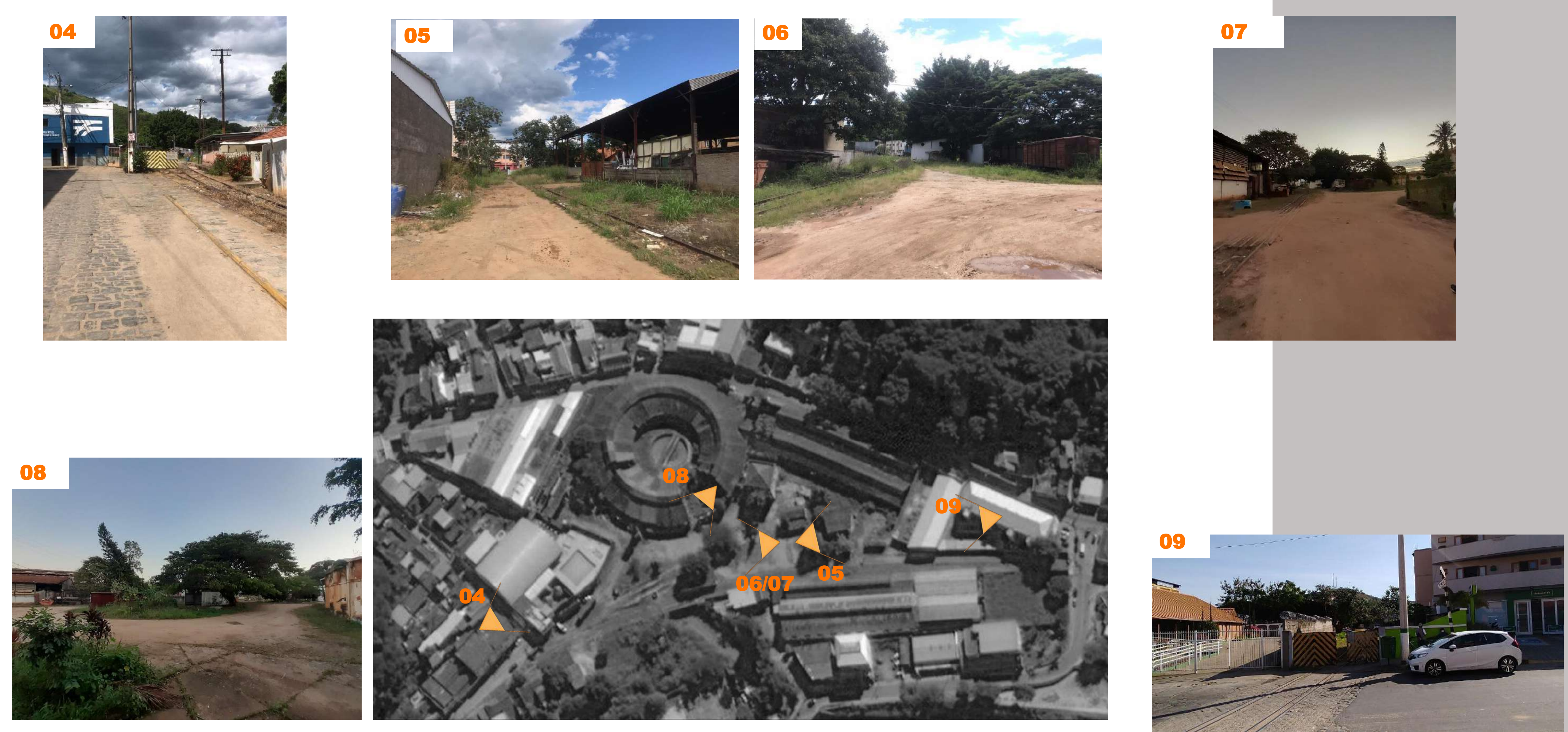


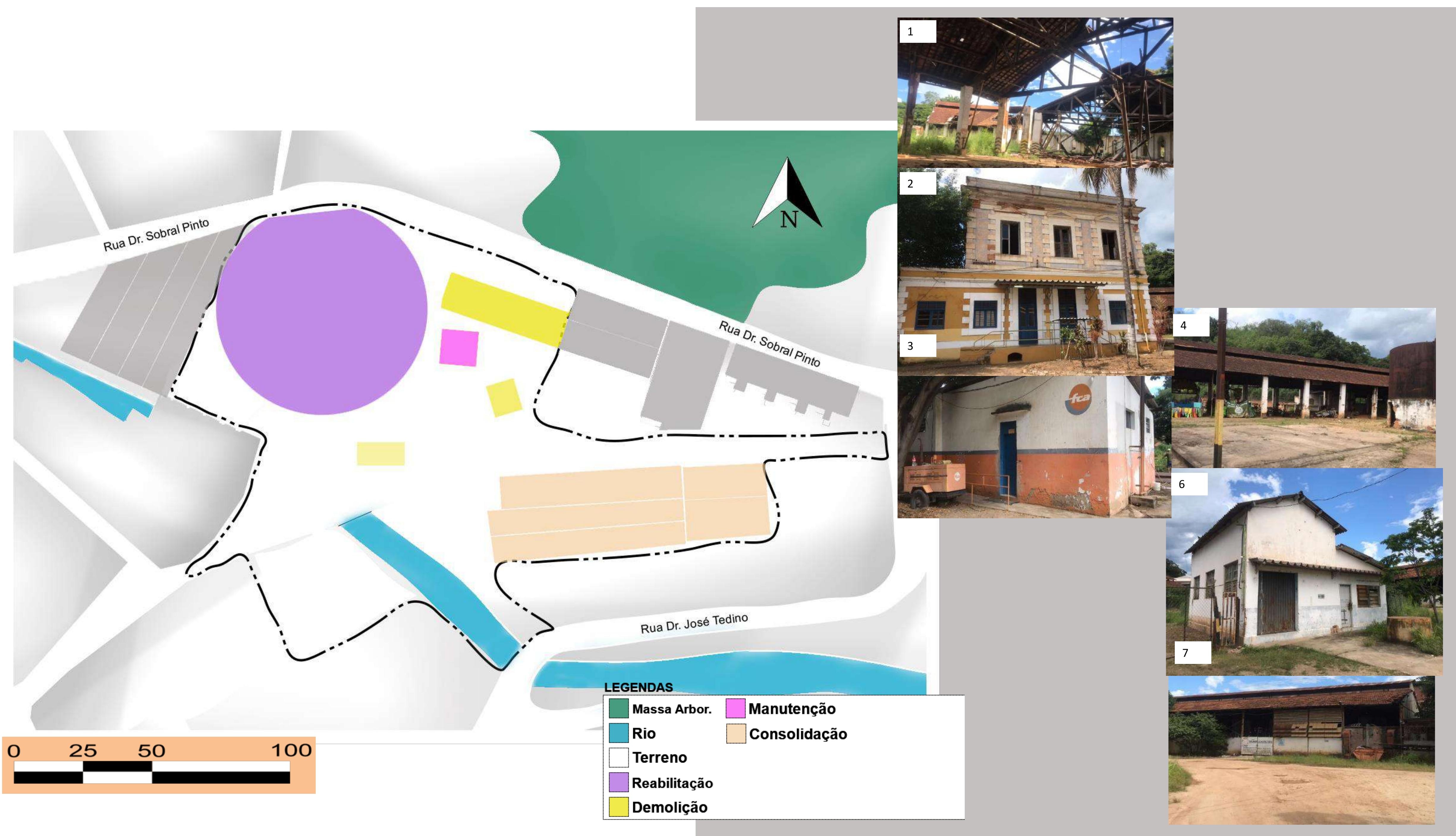




\section{LEGISLAÇÃO}

ZONEAMENTO: ZONA DE USO INSTITUCIONAL E/OU RELIGIOSO - ZIR

\section{PERMITIDO}

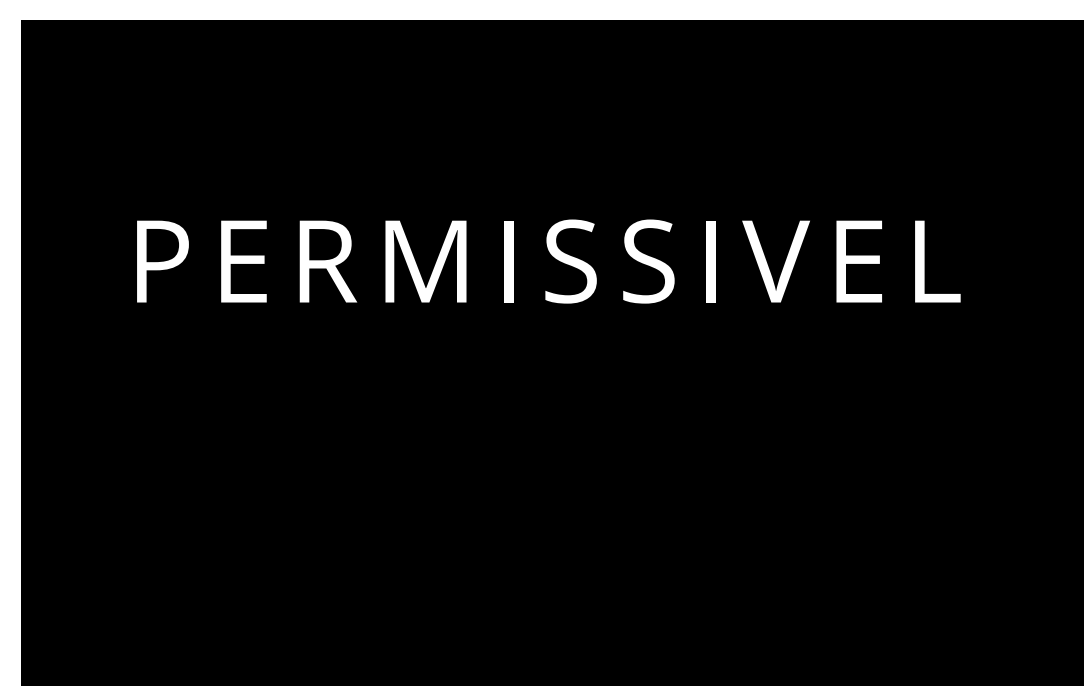

\section{TOLERADO}

$$
\text { LAZER }
$$

COMÉRCIO E

INSTITUIÇÕES

LAZER

SERVIÇO VICINAL
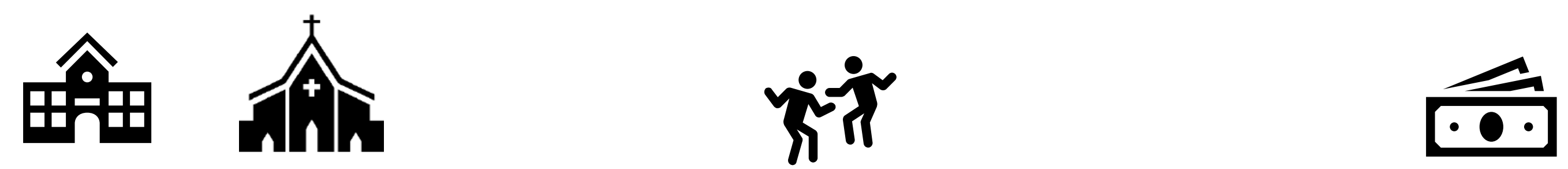

É permitido construção de novas edificações somente para usos permitidos e permissíveis, mas é permitido a realização de reformas e/ou ampliações de edificações existente para usos permitidos, permissíveis e tolerados da zona. 


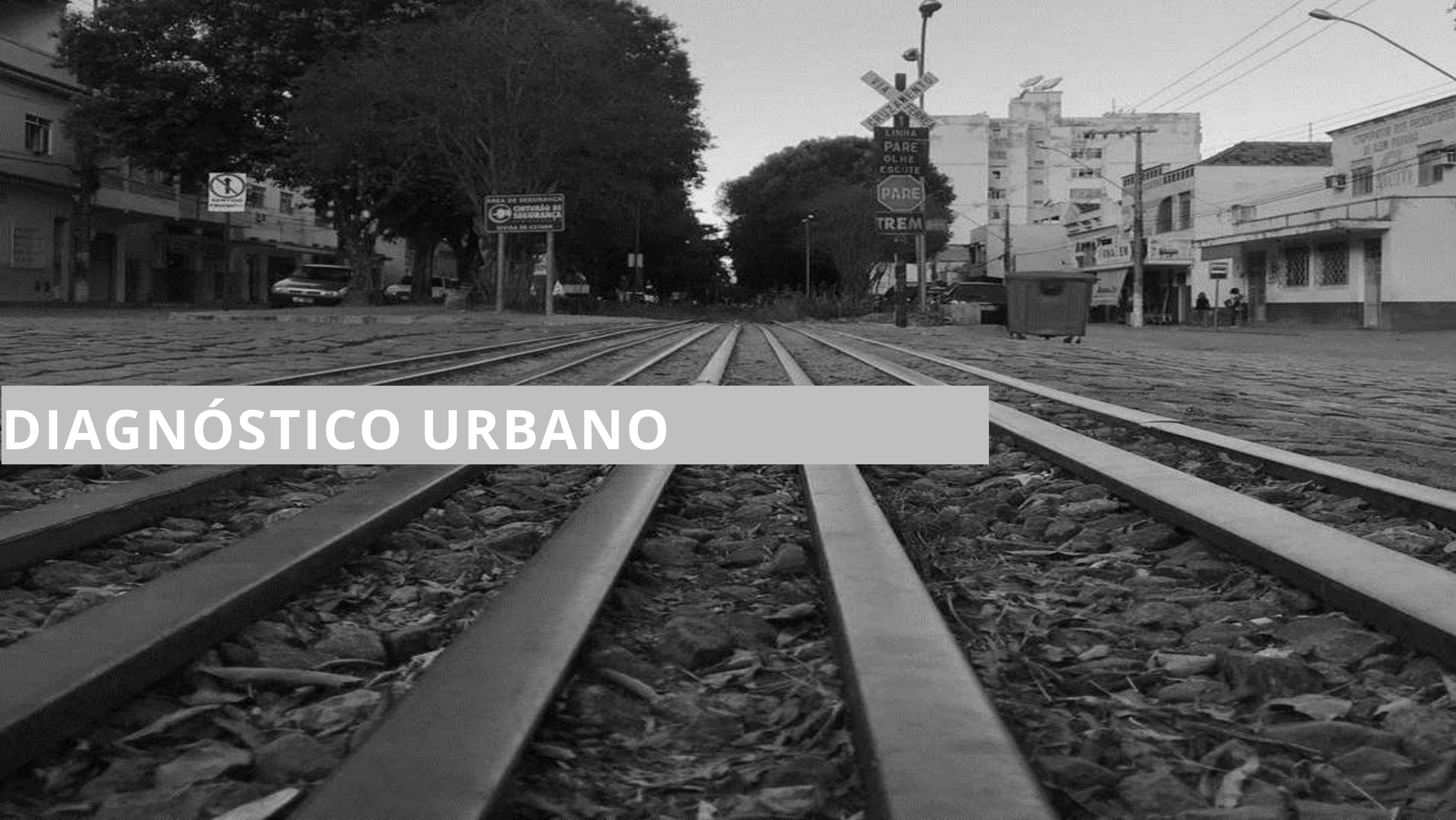




\section{DIAGNÓSTICOS SINTESE}

VIA LOCAL

VIA ARTERIAL

PONTOS DE ÔBINUS

PONTOS DE TAXI

PONTOS DE ENCONTRO

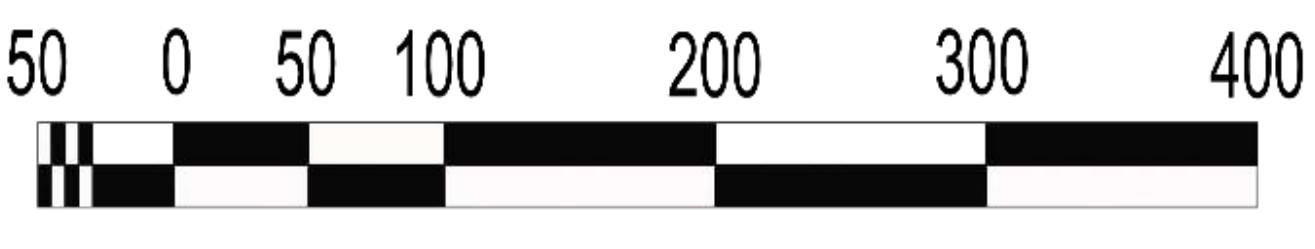




\section{ANÁLISE FOFA}

- FORÇAS

Próximo ao centro

Diversos usos

Diversos Pontos de encontro

- OPORTUNIDADES

Integração

Turismo

Novo espaço de encontro

Melhor estrutura para feirantes
- FRAQUEZAS

Vazio Urbano

Falta de segurança

Edifícios Degradados

\section{- AMEAÇAS}

Aumento de trânsito 


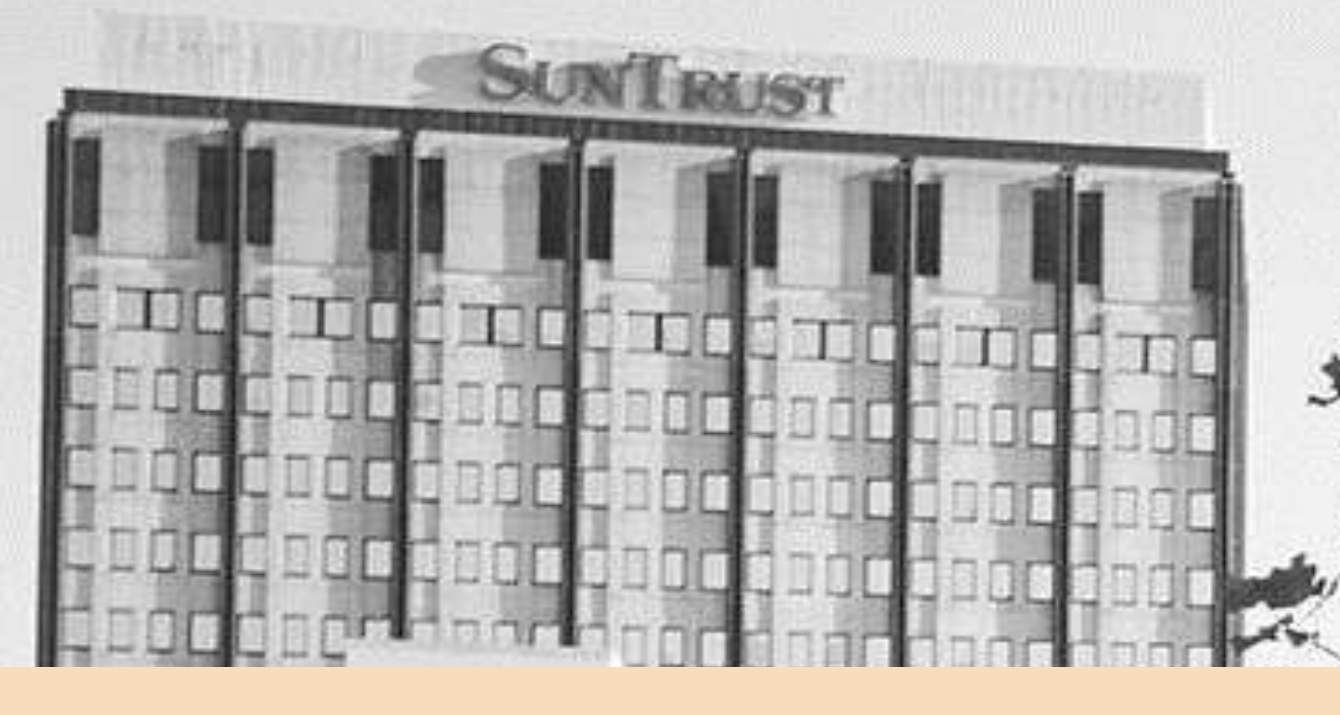

sh ESTUDOS DE CASO

ea $\quad 18=\pi$

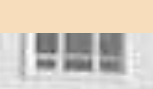

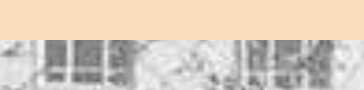

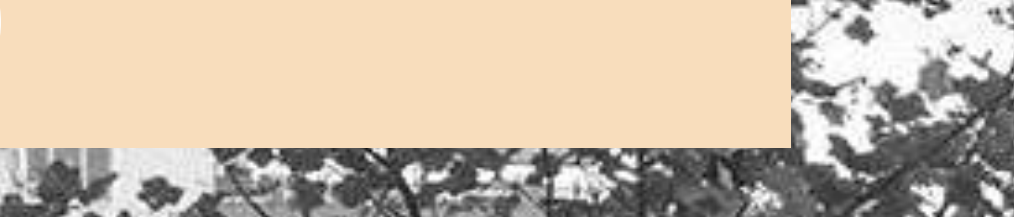
so

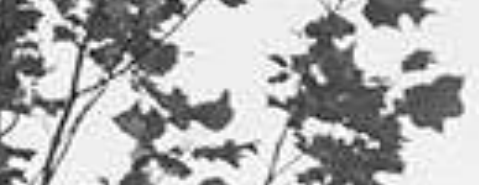
a

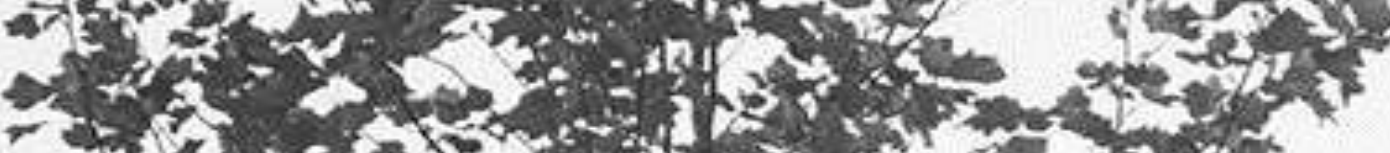

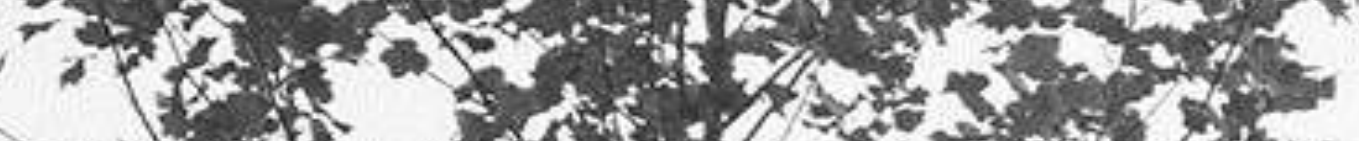
$8+70.12$ 4. ${ }^{2}+2$ , t. (2) ifilifil|

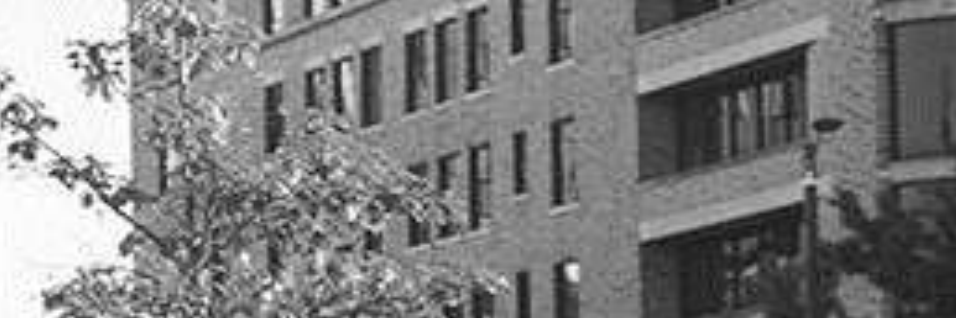

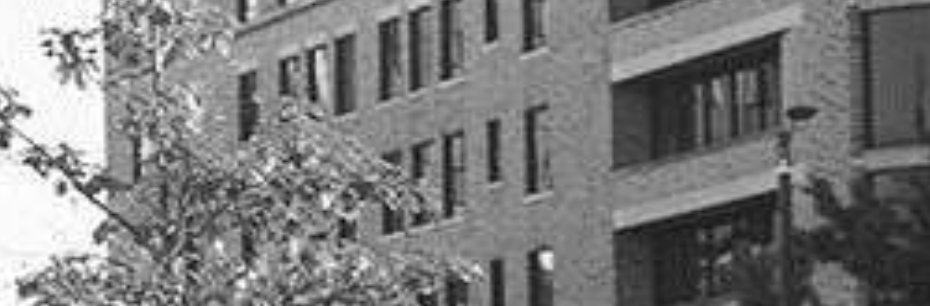

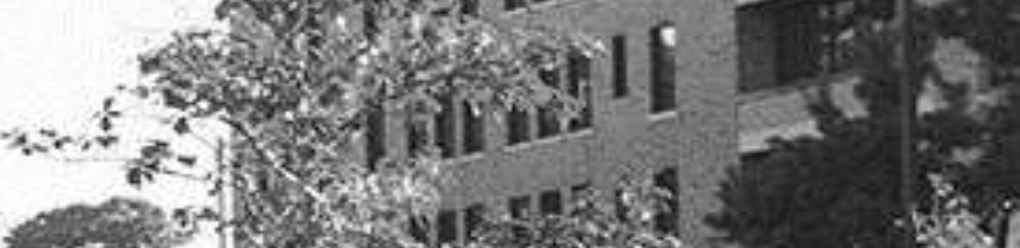

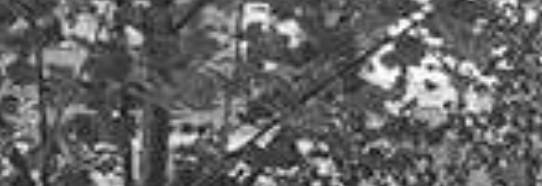
7 .

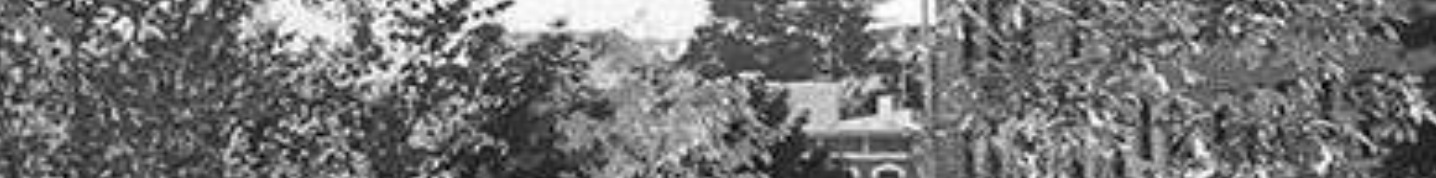

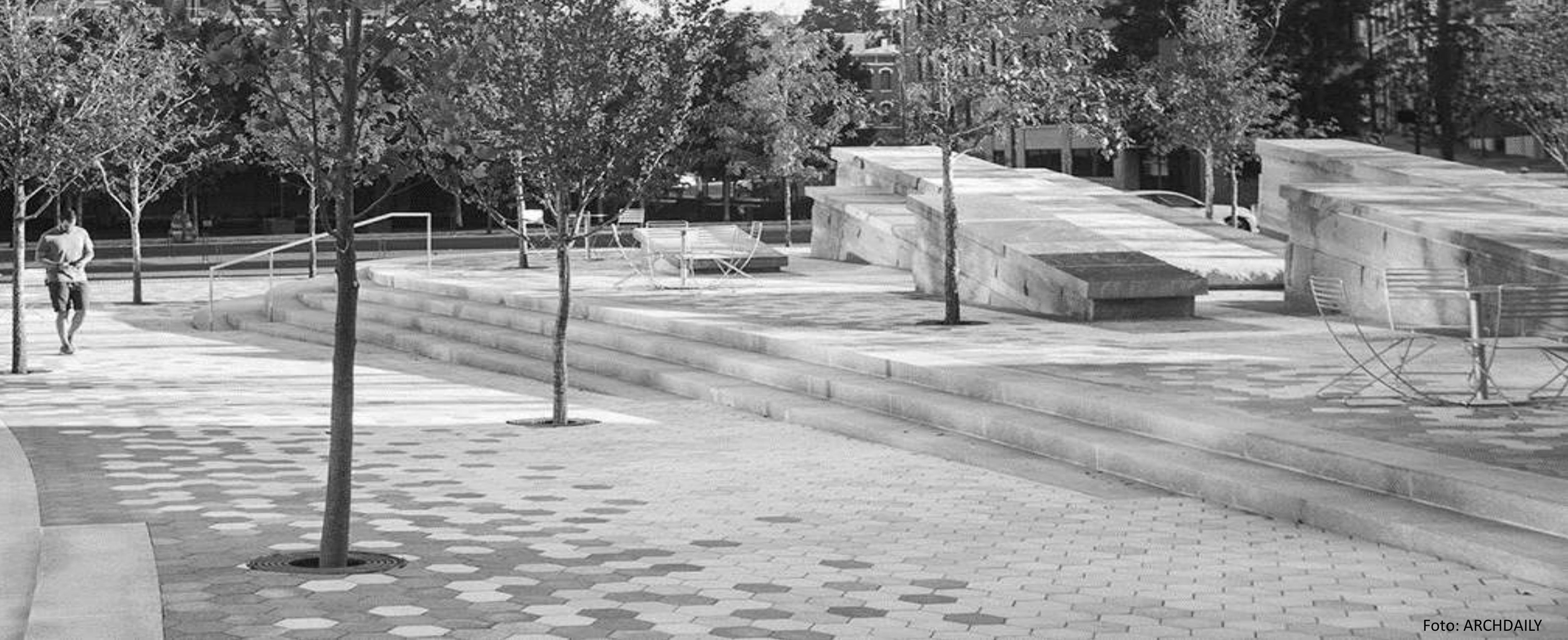



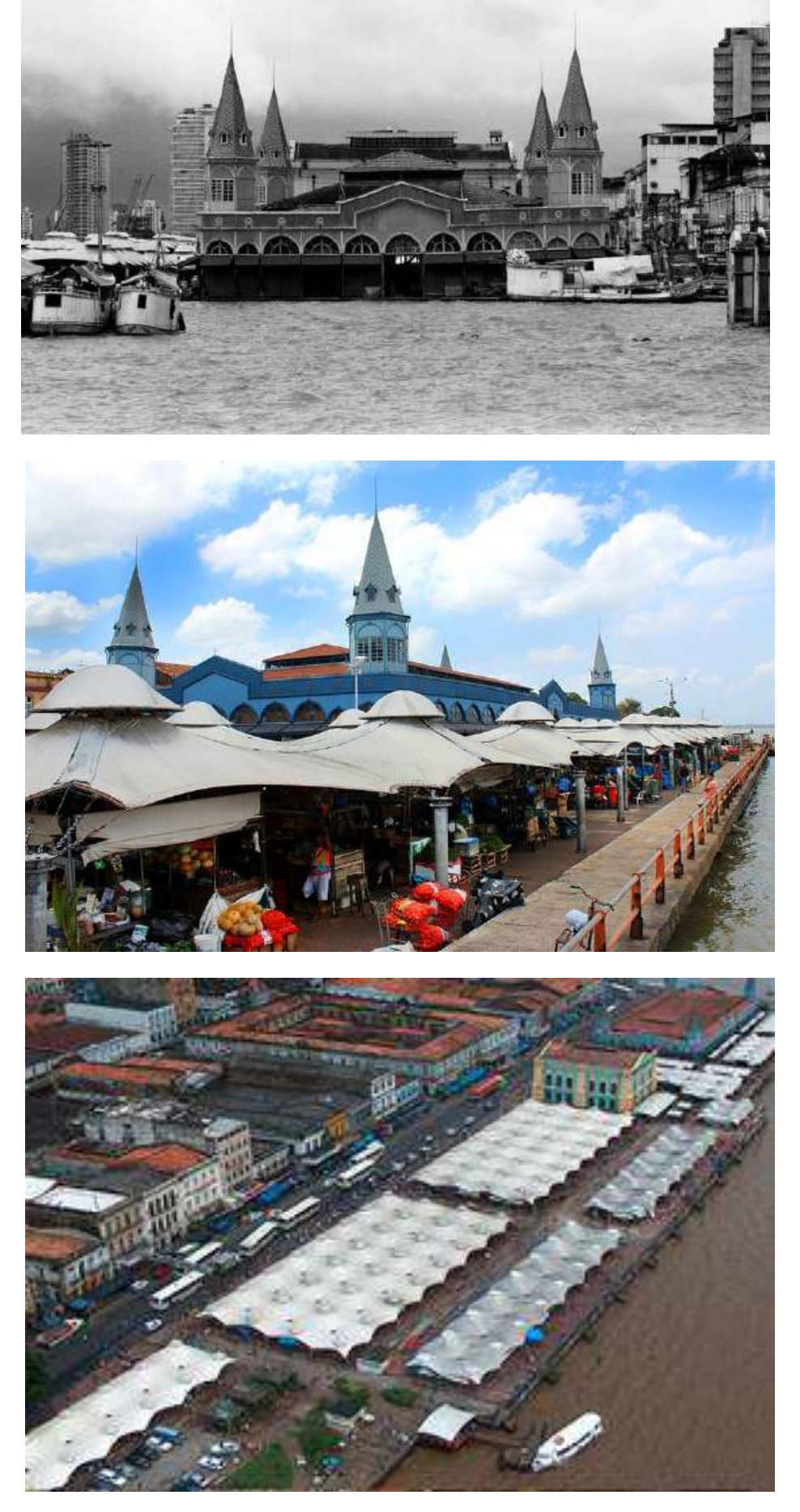

\section{MERCADO VER-O-PESO}

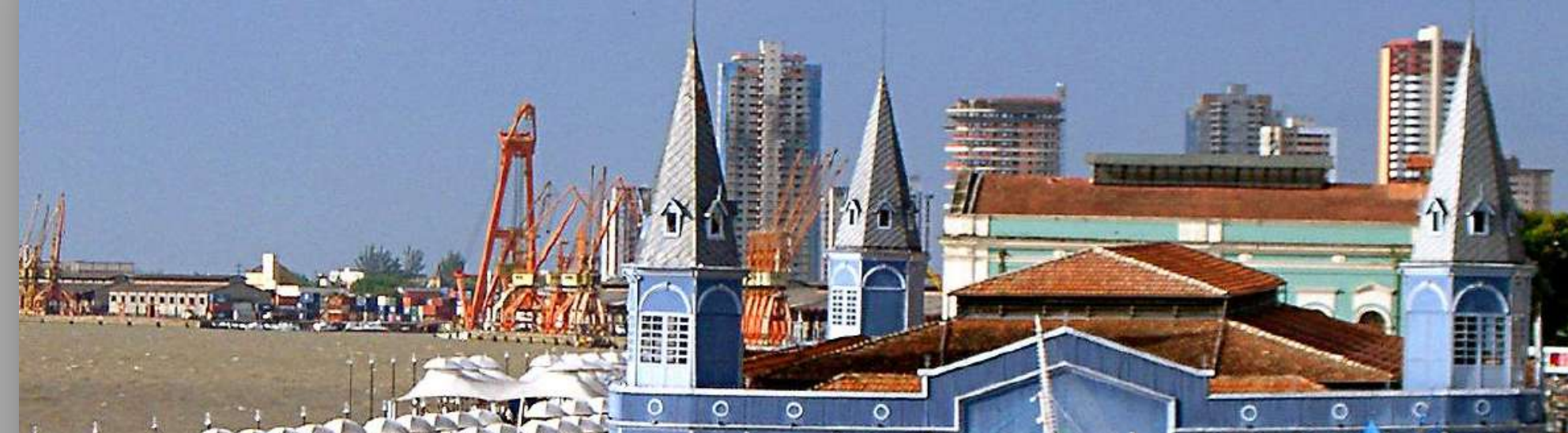

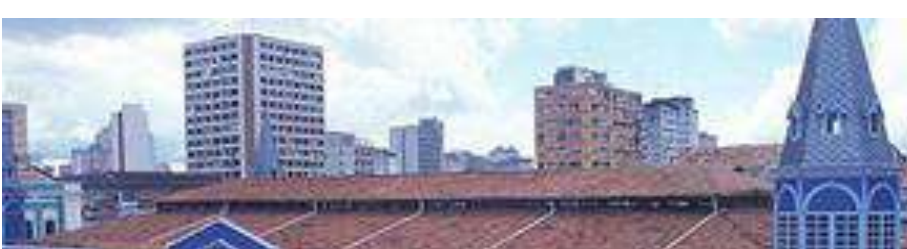

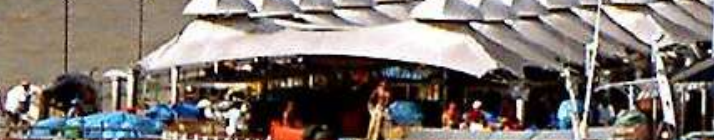

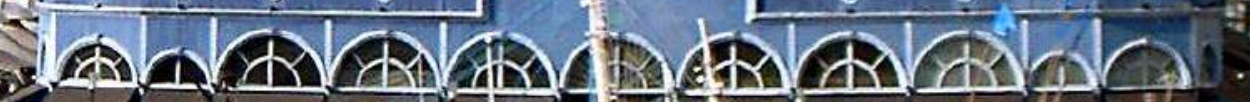

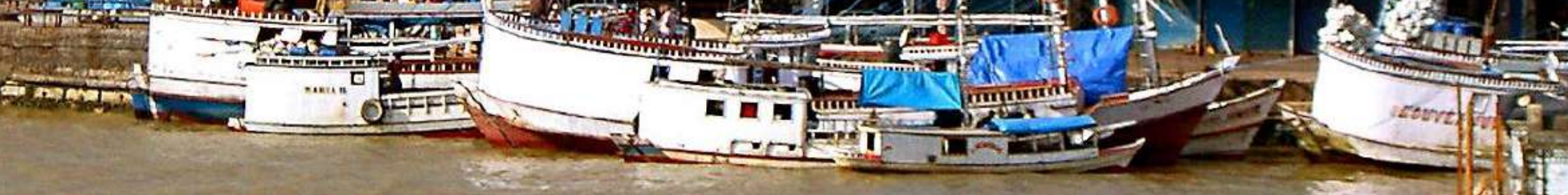

and

Arquitetos: Flávio Ferreira Arquitetura e Urbanismo Localização: Belém - Pará Área: Aprox. $25.000 \mathrm{~m}^{2}$ Ano do projeto: 1901 Ano da intervenção: 1998 


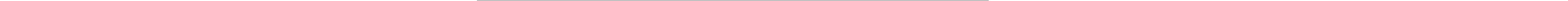




\section{ESPAÇO CULTURAL VITOR JARA}

Arquitetos:

L'Escaut e Bureau d'etudes Weinand Localização: Soignies, Bélgica

Área: $1950 \mathrm{~m}^{2}$

Ano do projeto: 2005

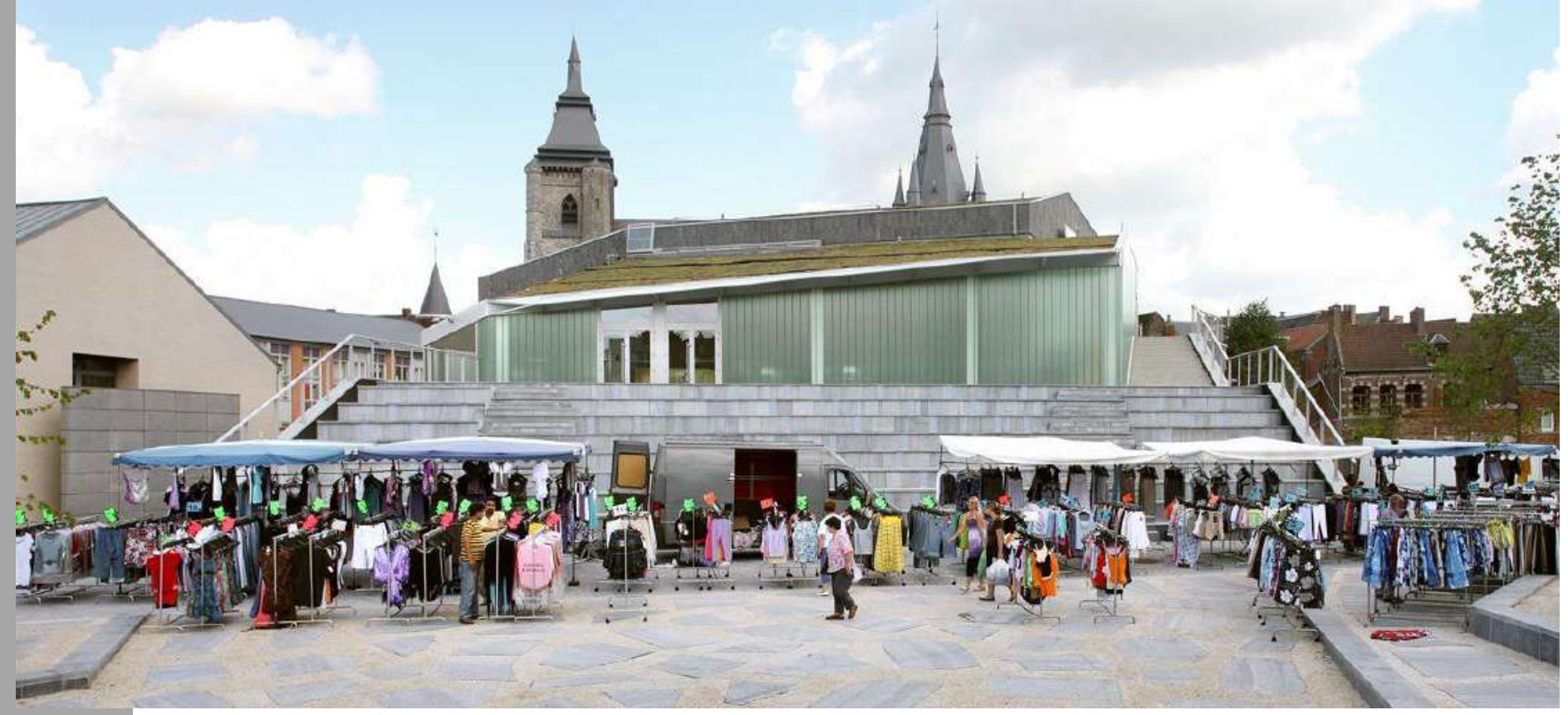

Extensão do espaço público

ARQUITETÔNICA 


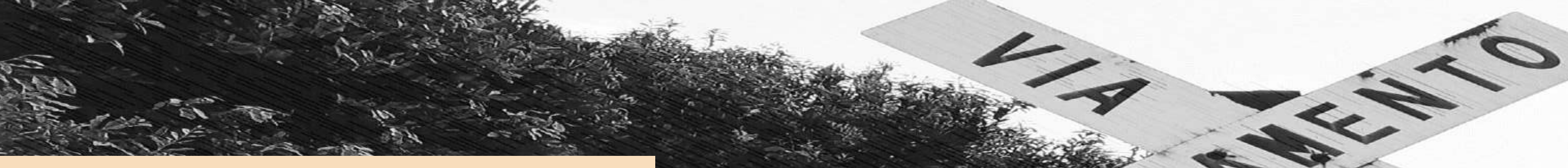

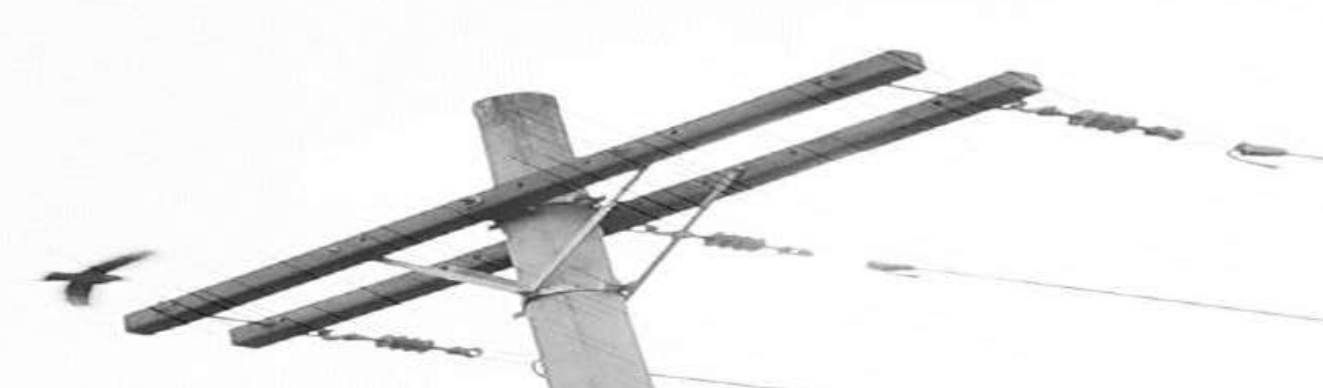
PROPOSTA

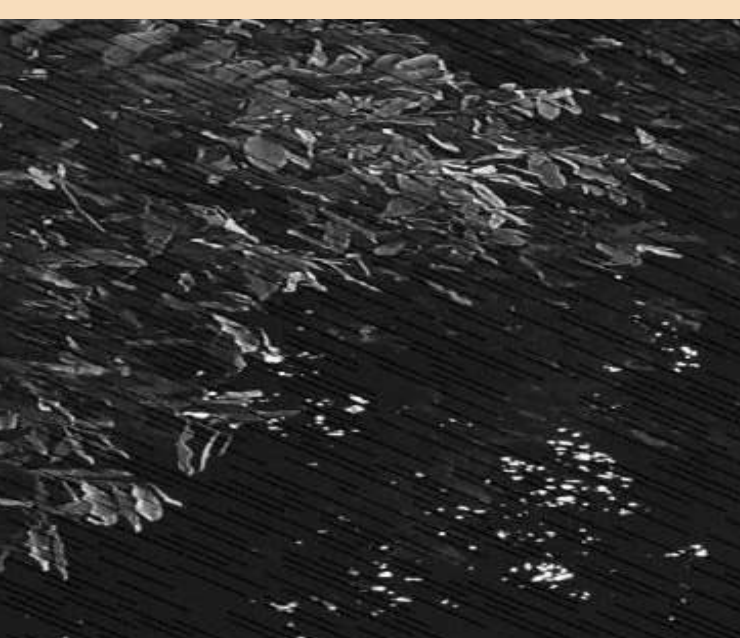

is

राष

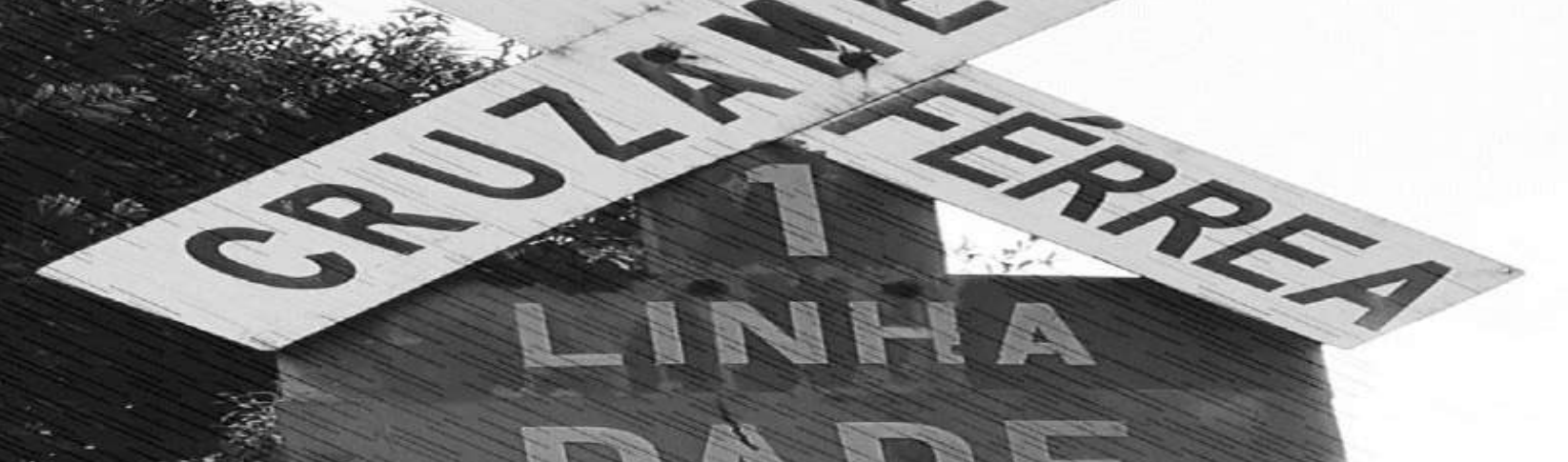

P/ND=

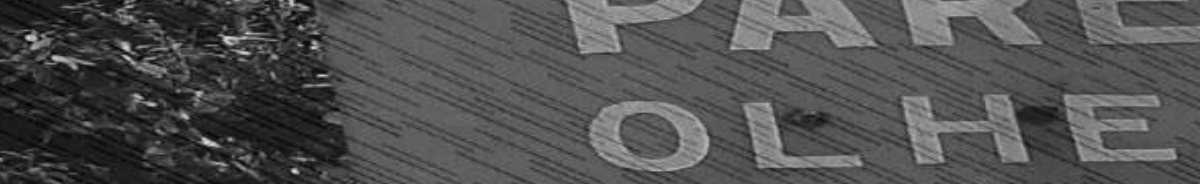

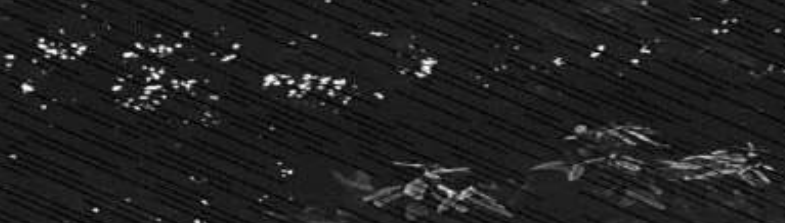

S $E$ SCOUTE

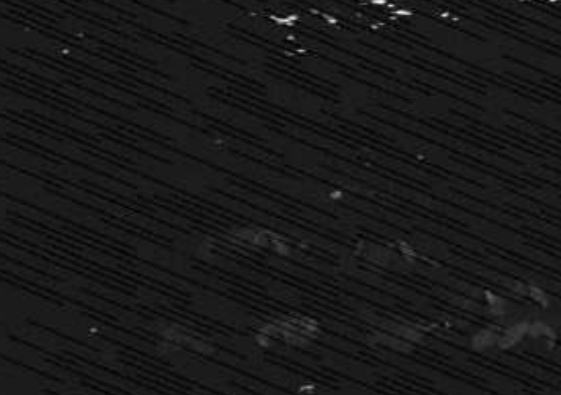

and an is int?

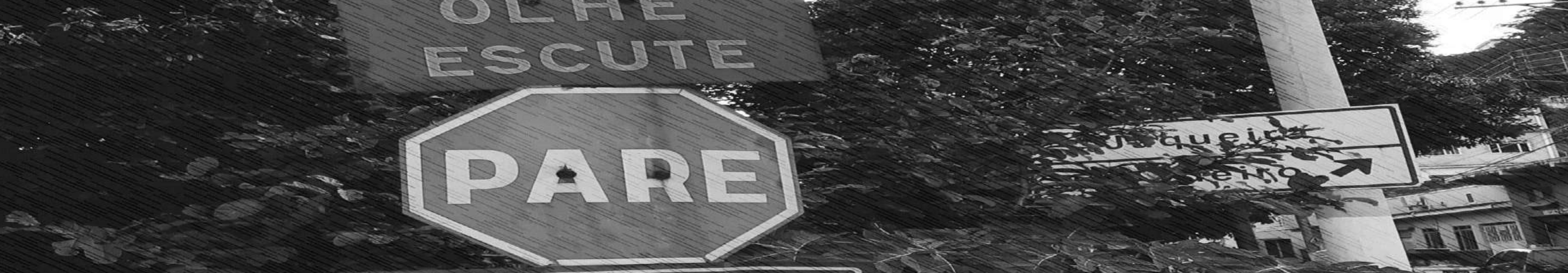
$\left(5^{2}\right.$

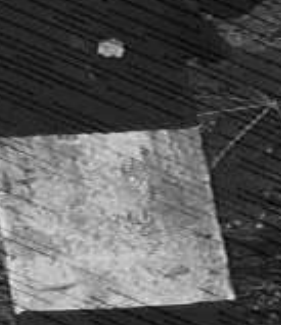

T.

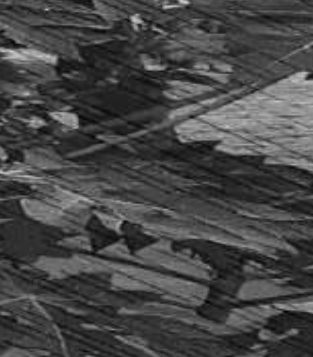

$+2=3$

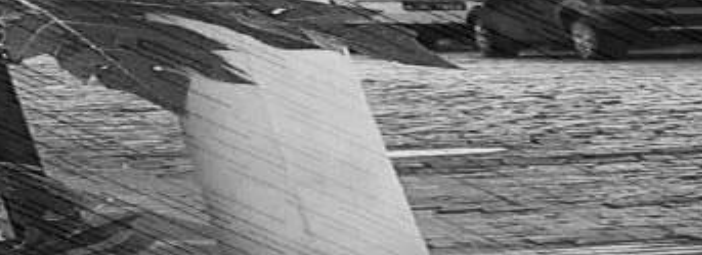

$3+2$ 


\section{CONCEITO/PARTIDO}

\section{RESSIGNIFICAR}

A partir das intervenções no existente, trazer um novo significado a um conjunto que atualmente encontra-se vazio e mantendo a história do local viva.

DISTINGUIBILIDADE NOVO USO INTEGRAÇÃO AO ENTORNO ESPAÇOS DE RECORDAÇÃO ESPAÇOS DE PERMANÊNCIA 


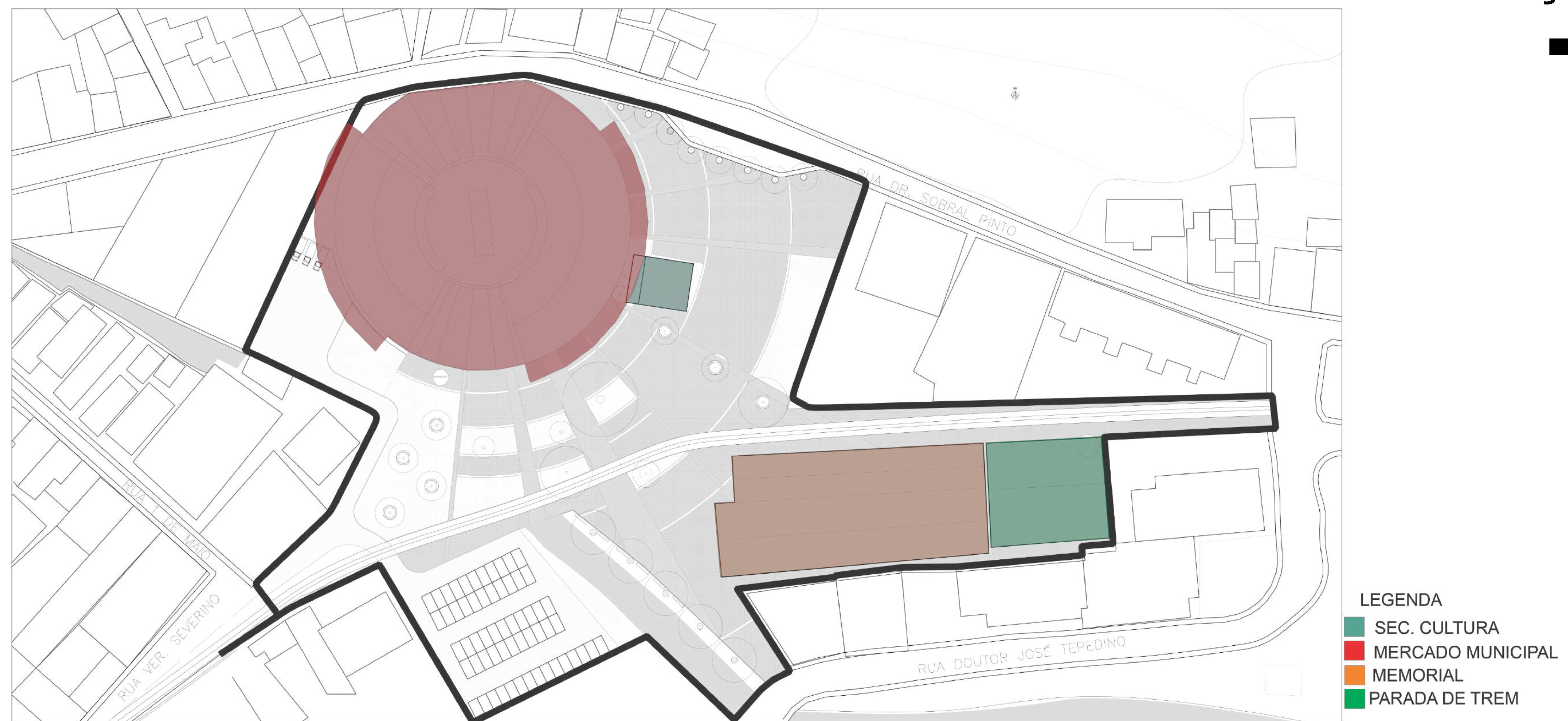


DIAGRAMA - FLUXOS

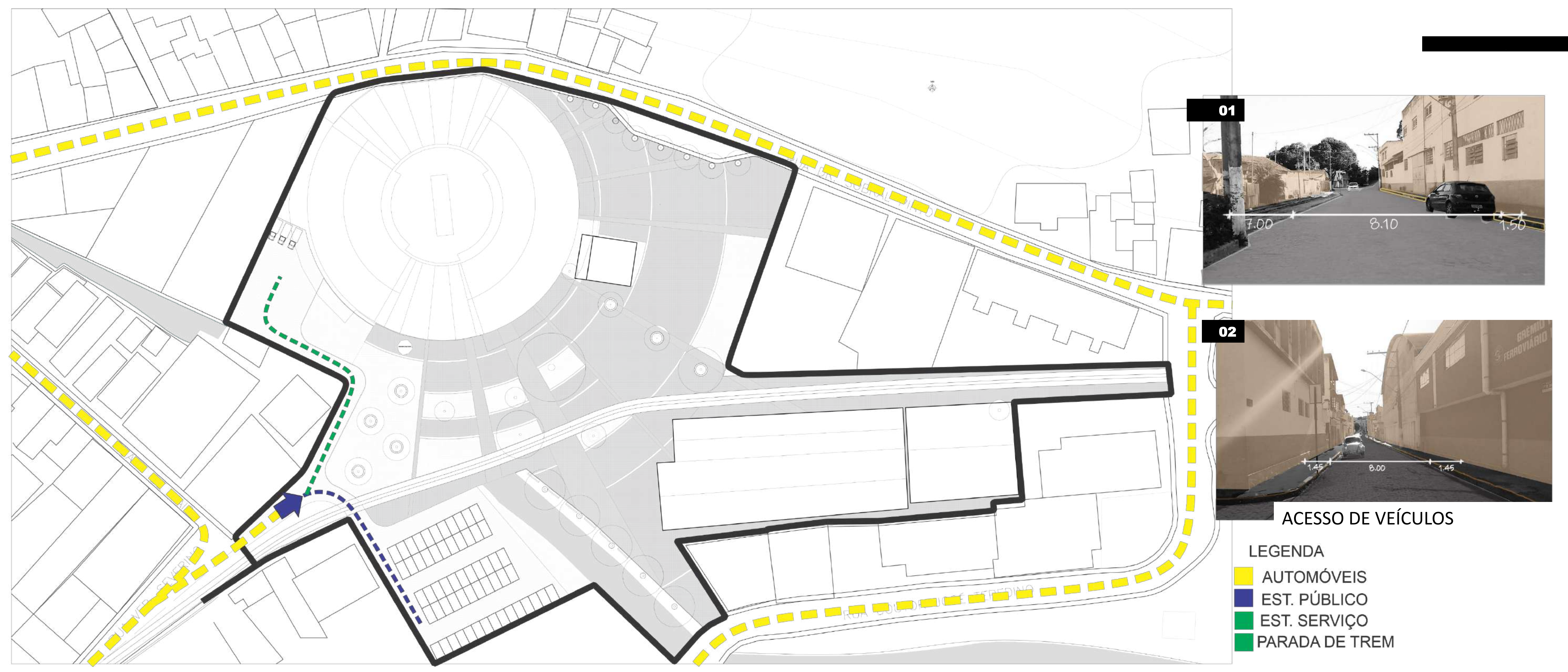




\section{DIAGRAMA - FLUXOS}

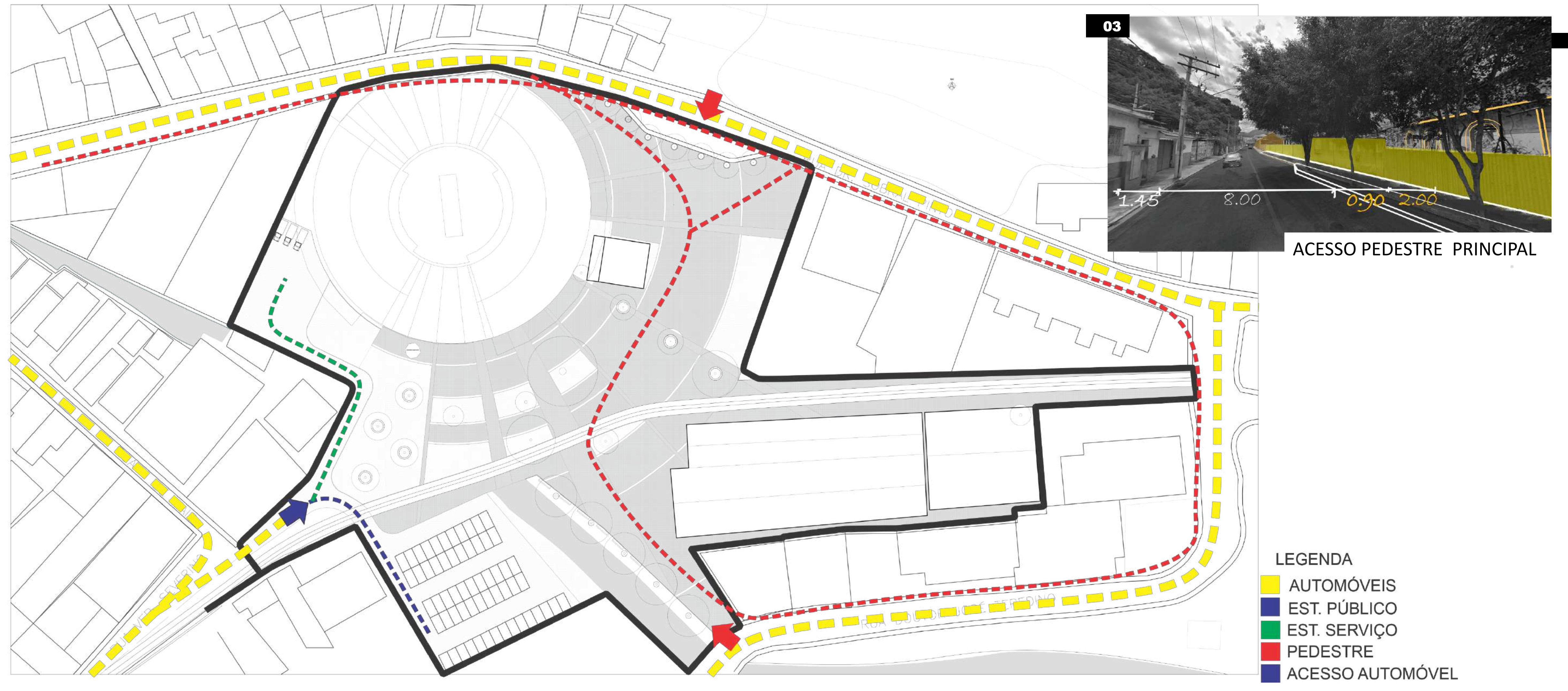


DIAGRAMA - ILUMINAÇÃO

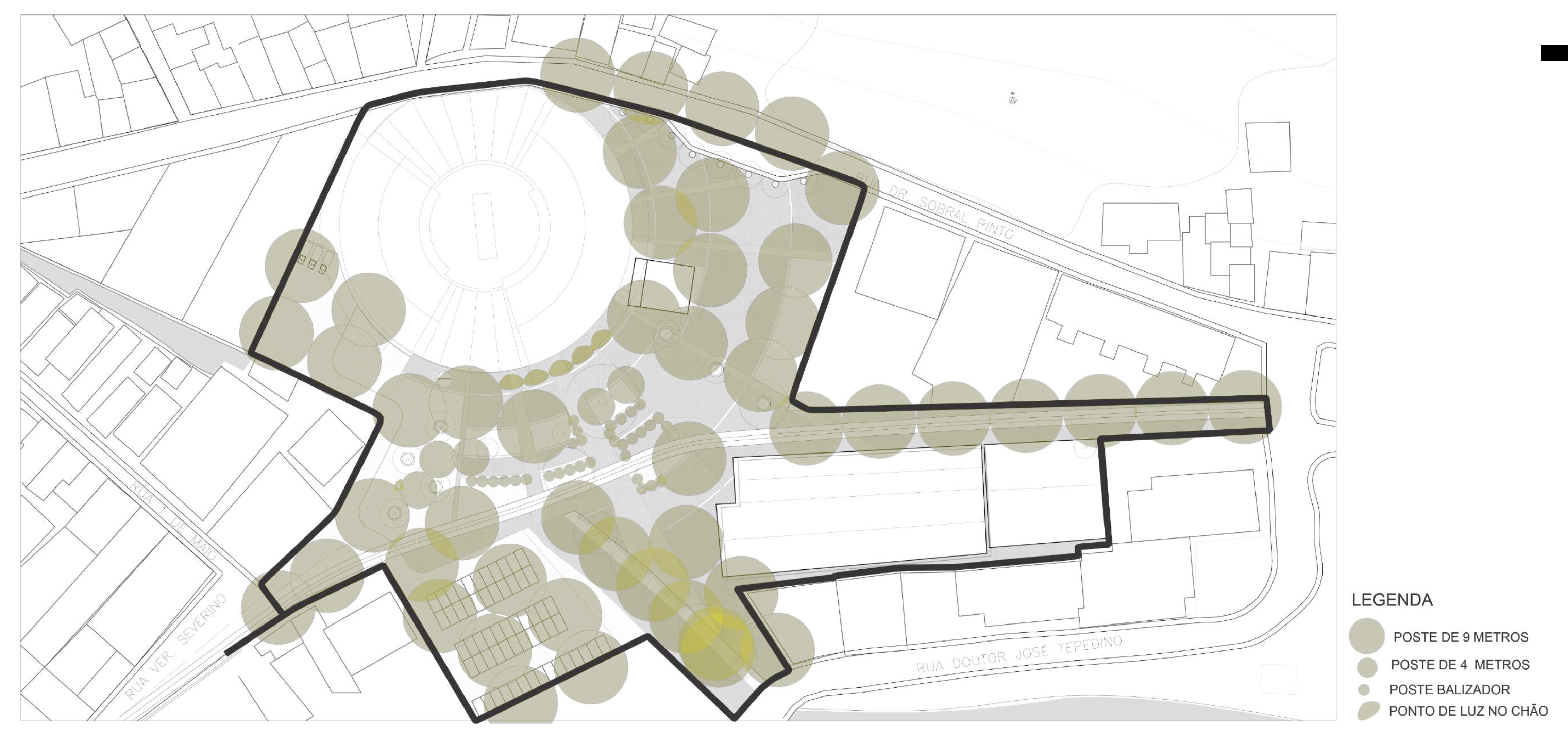




\section{DIAGRAMA - ARBORIZAÇÃO}

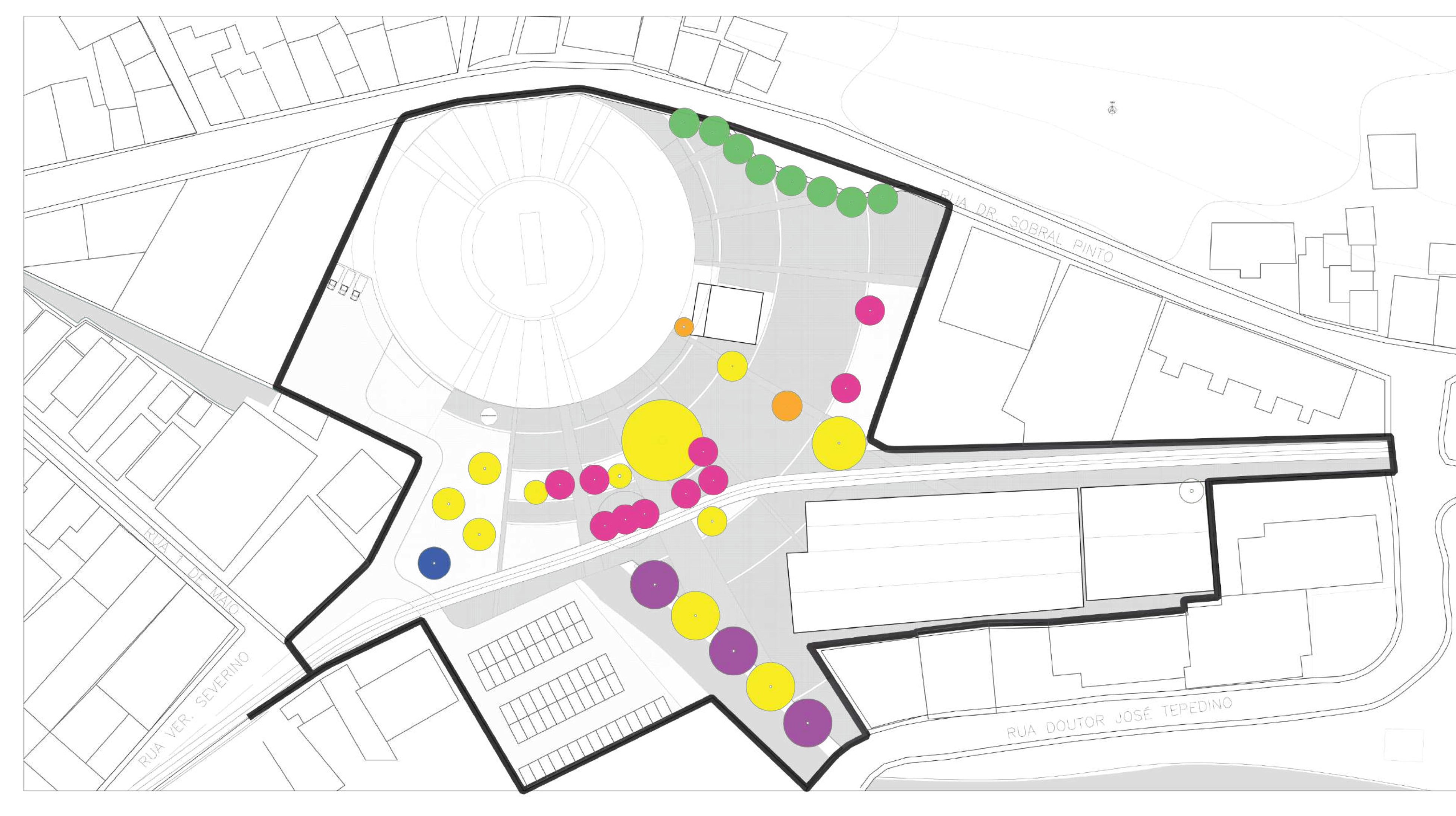

JACARANDA ROSA

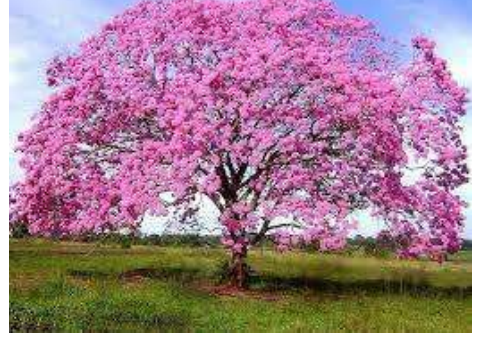

QUARESMEIRA

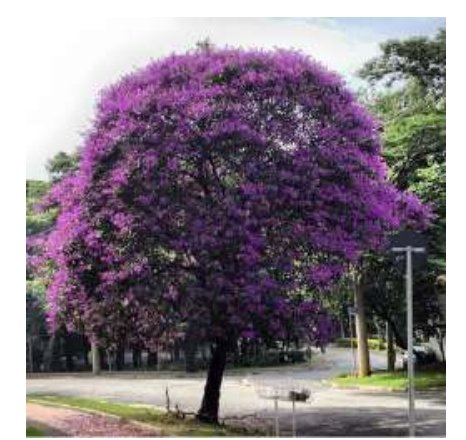

SAPUCAIA

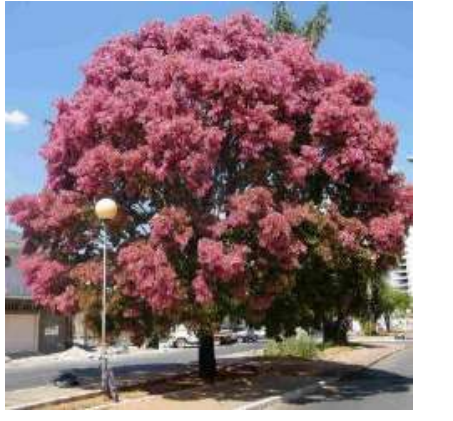

OITI

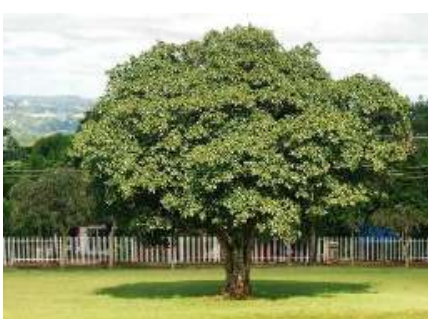

PALMEIRA

IMPERIAL

LEGENDA

EXISTENTES

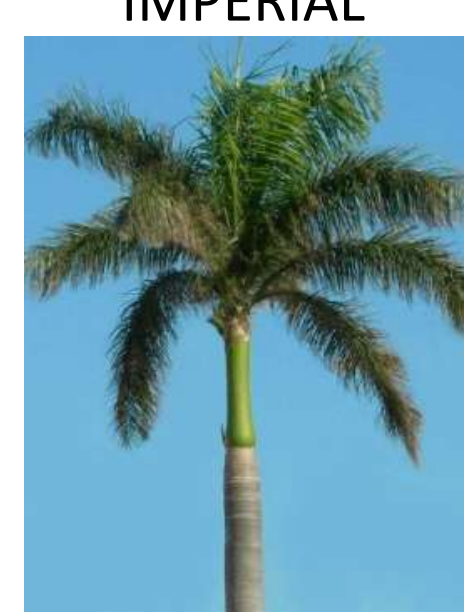

JACARANDA

- SAPUCAIA

- QUARESMEIRA

O OITI

- PALMEIRA IMPERIAL 


\section{DIAGRAMA - PAISAGISMO}

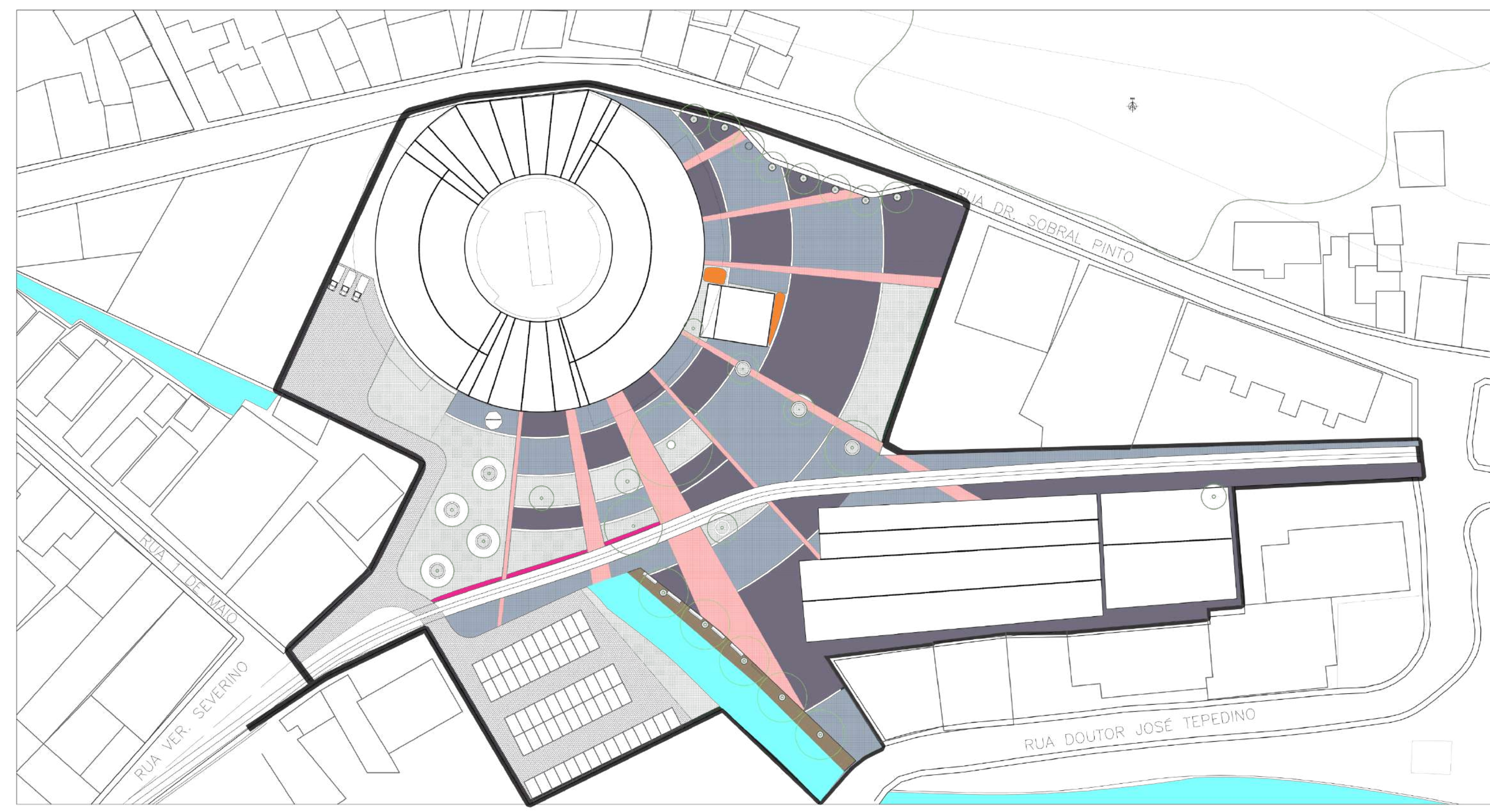

INTERTRAVADO

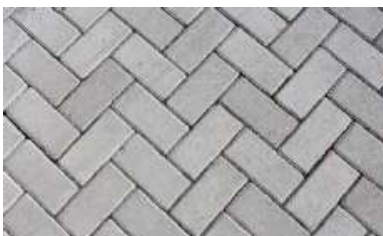

GRAMA CATARINA biveris 4 ind

PAMEIRA GARRAFÃO

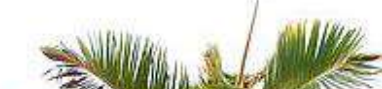

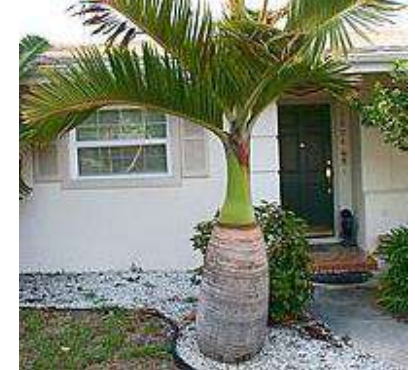

MEGADRENO
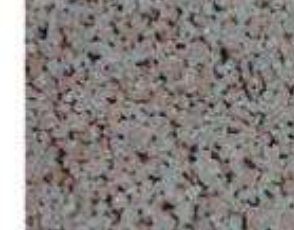

RONZE Terracota

masmongase?

3x.

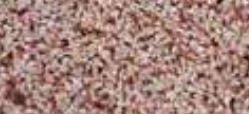
PRATA Cerámica
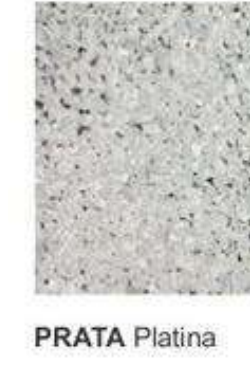

MARIA SEM VERGONHA

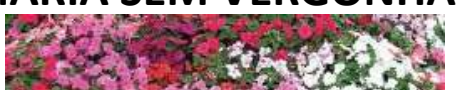

LEGENDA
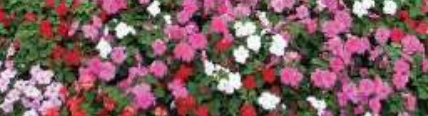

MEGADRENO NA COR GRAFIT

MEGADRENO NA COR VERMELHO

MEGADRENO NA COR CINZA

PISO INTERTRAVADO

GRAMA-CATARINA

PALMEIRAS GARRAFÃo

MARIA SEM VERGONHA 


\section{IMPLANTAÇÃO}

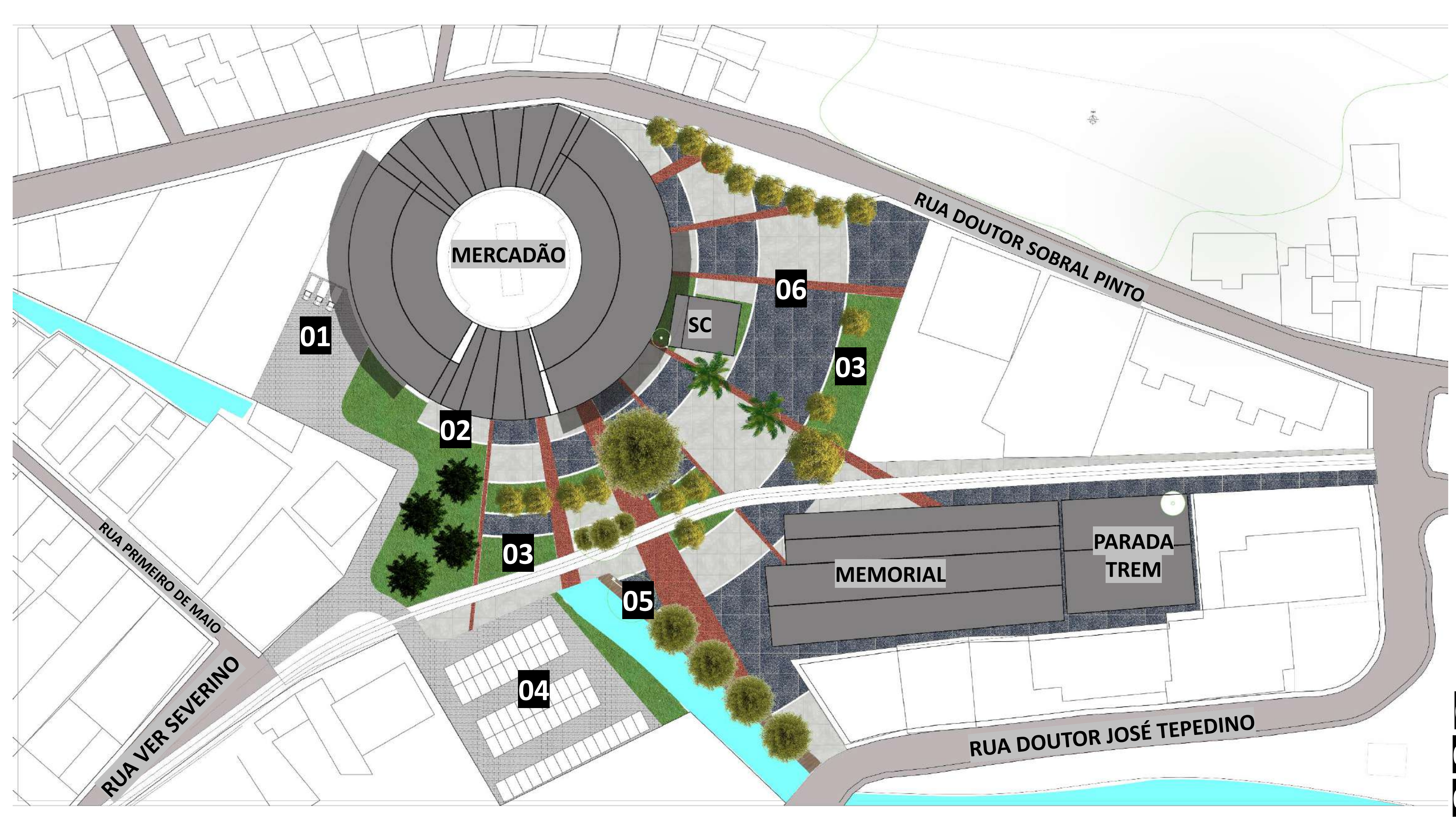

LEGENDA

01 - CARGA E DESCARGA

02- CAIXA D'AGUA

03 - PERGOLADO

04-ESTACIONAMENTO

05 - DECK DE PESCA

06 - ESPAÇO LIVRE 


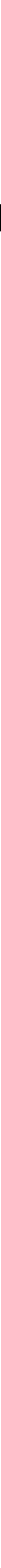




\section{MOBILIÁRIO URBANO}
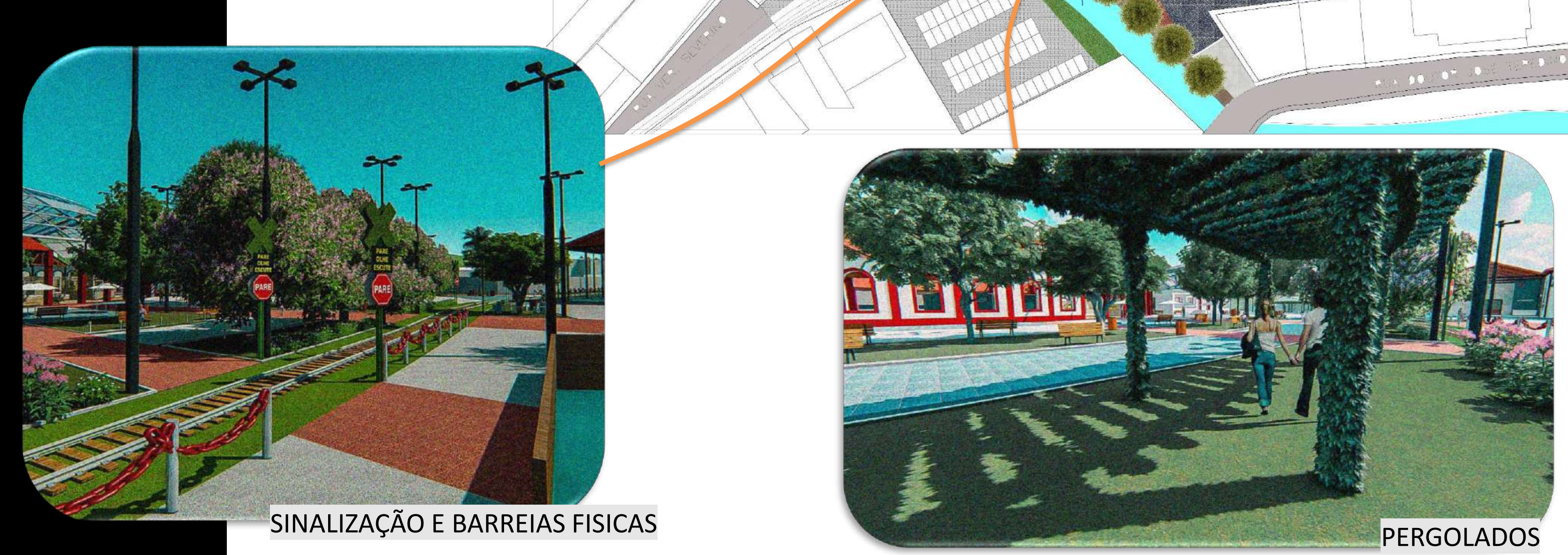
MERCADO MUNICIPAL
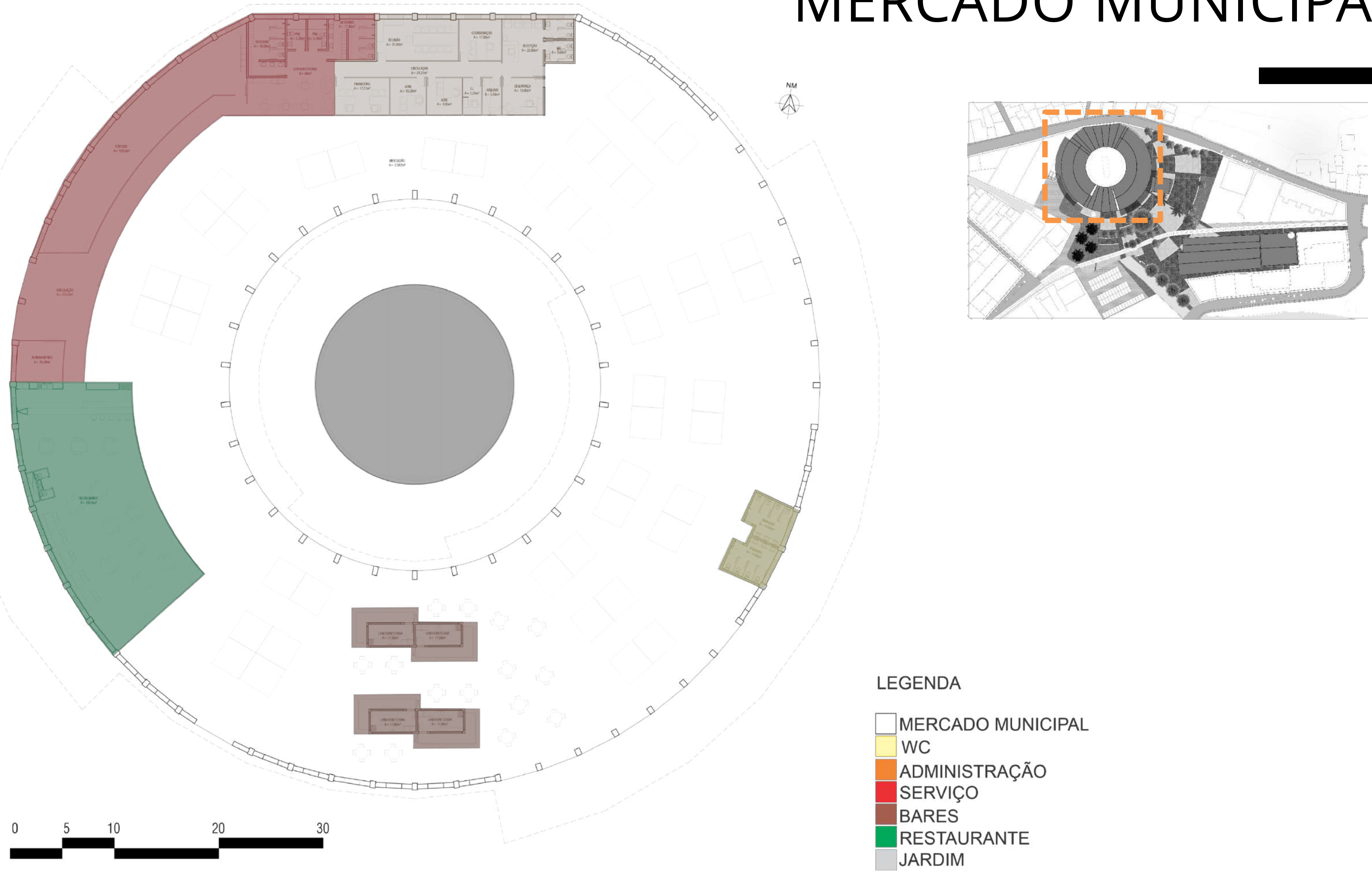

LEGENDA

$\square$ MERCADO MUNICIPAL

ADMINISTRAÇÃO

SERVIÇO

BARES

RESTAURANTE

JARDIM 
ADMINISTRAÇAO

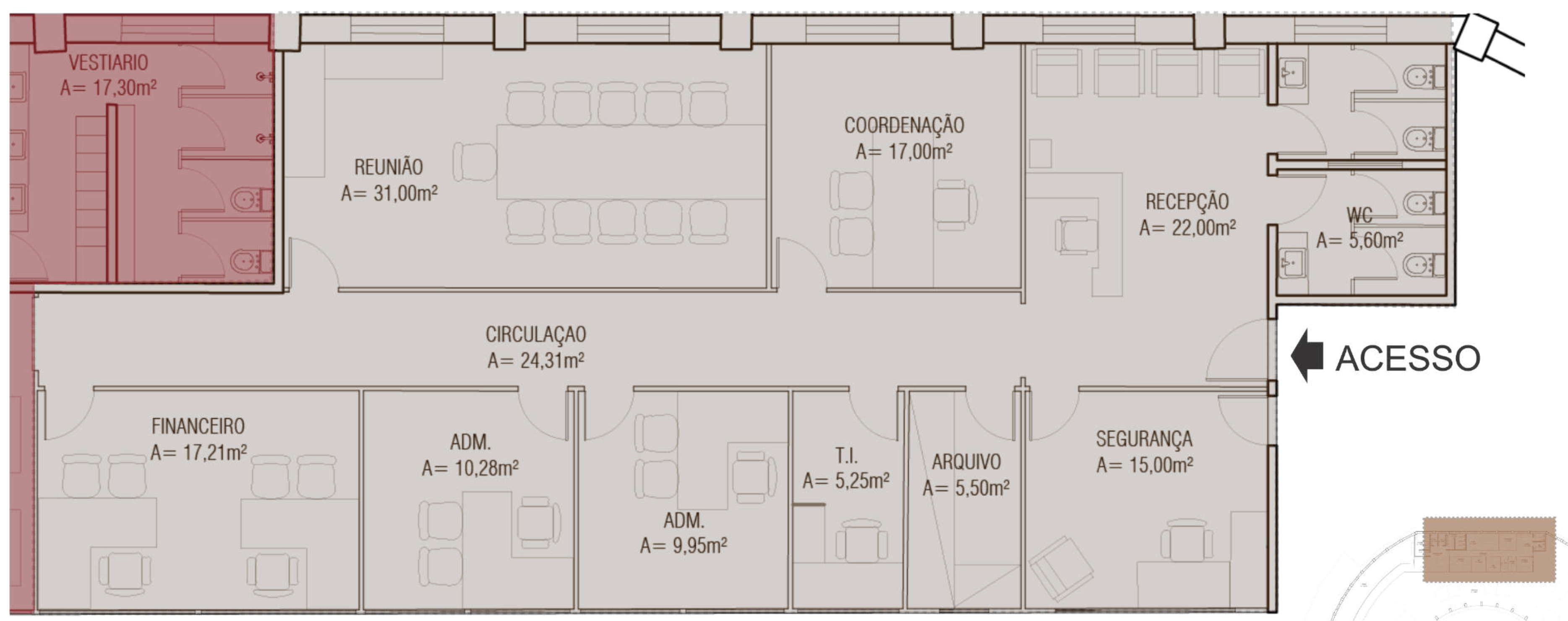

$\begin{array}{lll}0 & 5 & 10 \\ & \end{array}$ 
MERCADO MUNICIPAL
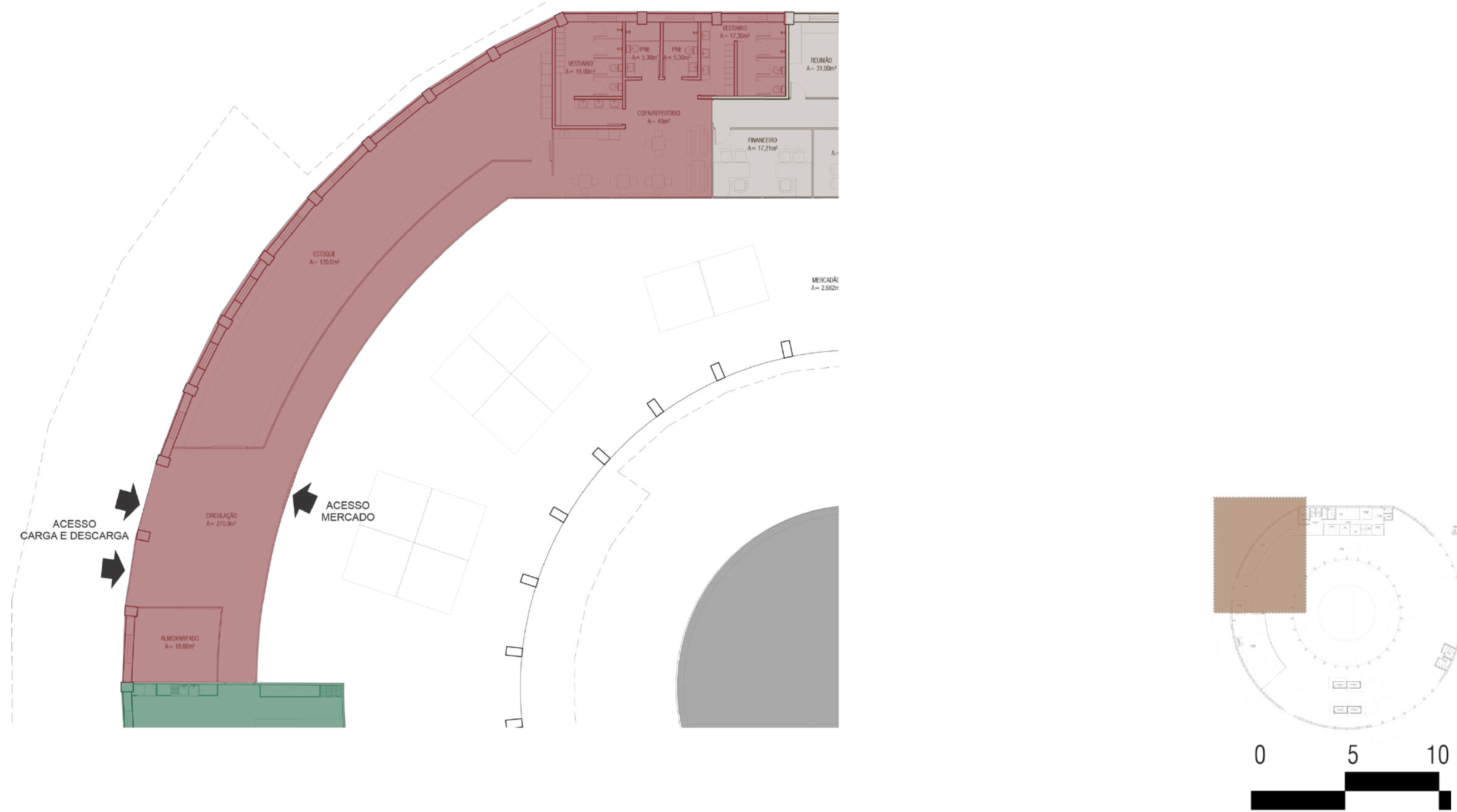


\section{MERCADO MUNICIPAL}

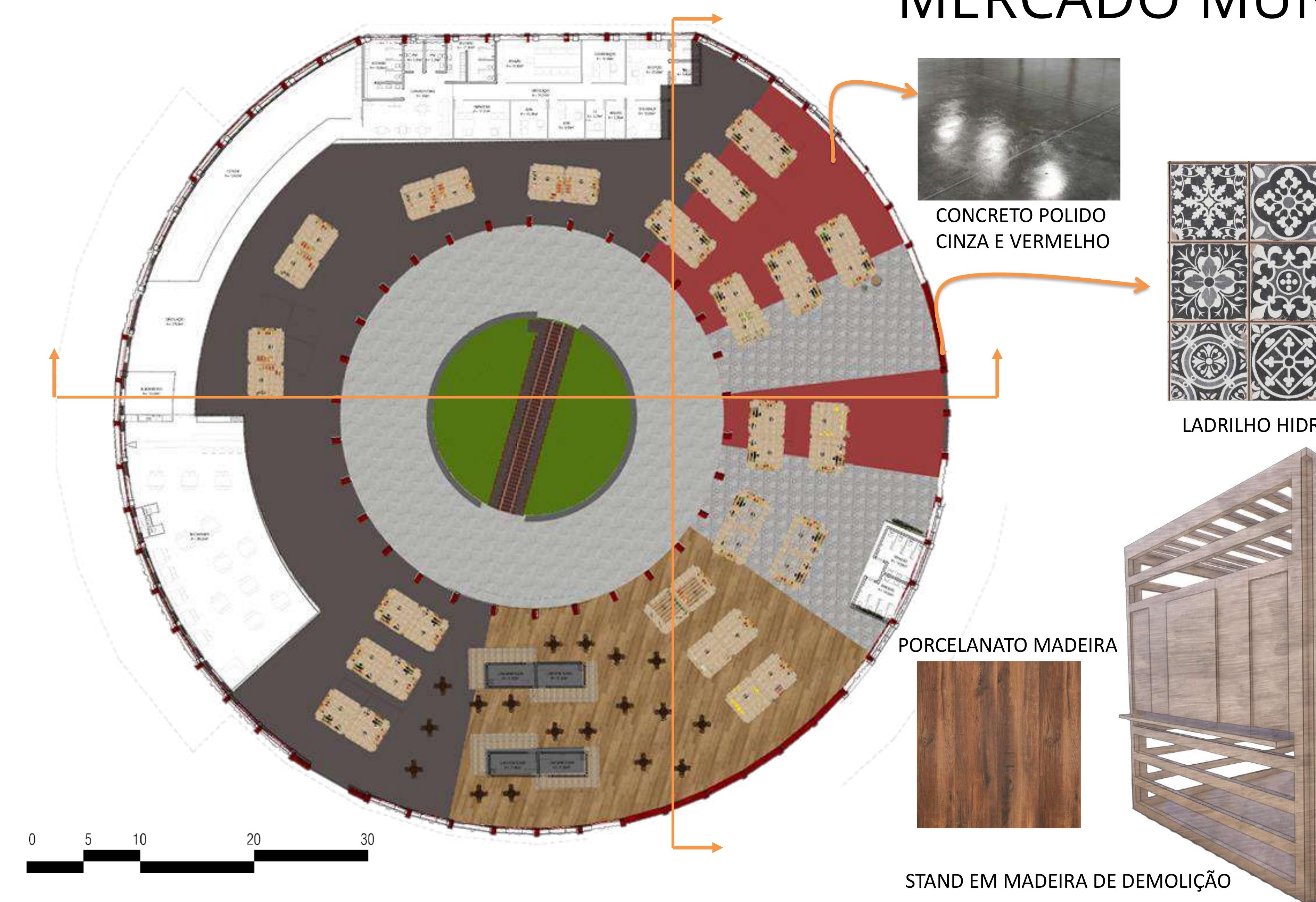


CORTES
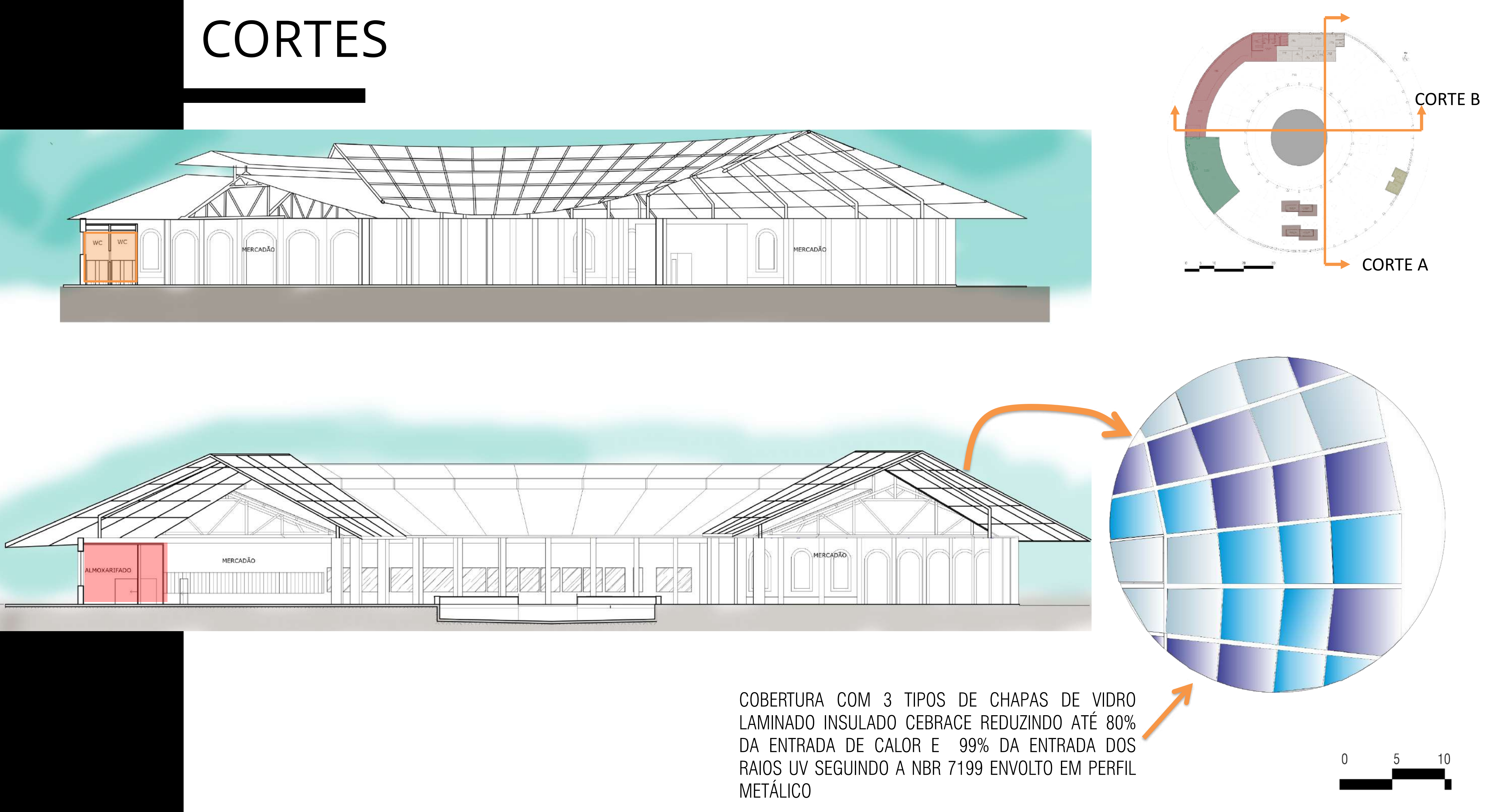


\section{FACHADAS}

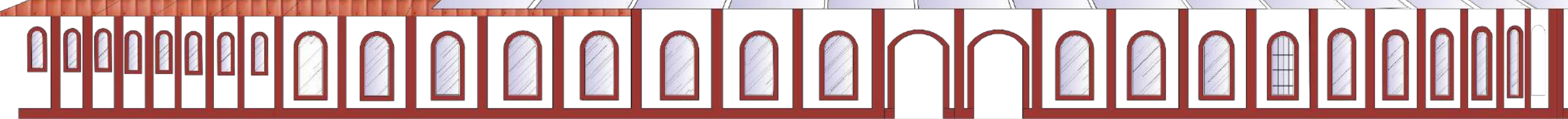

VISTA A

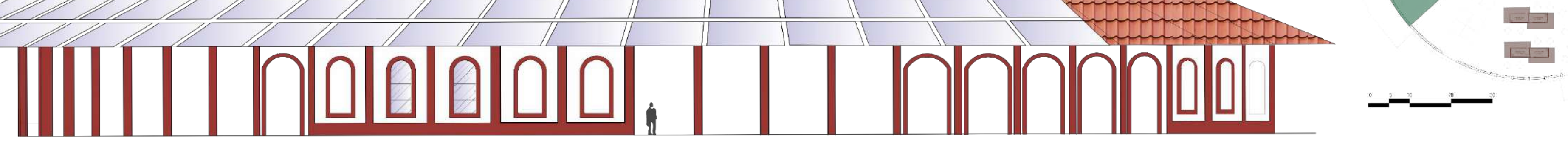

VISTA B

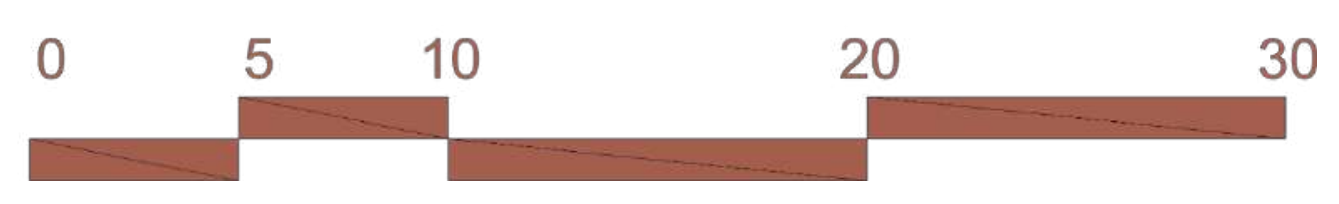




\section{MERCADO MUNICIPAL}
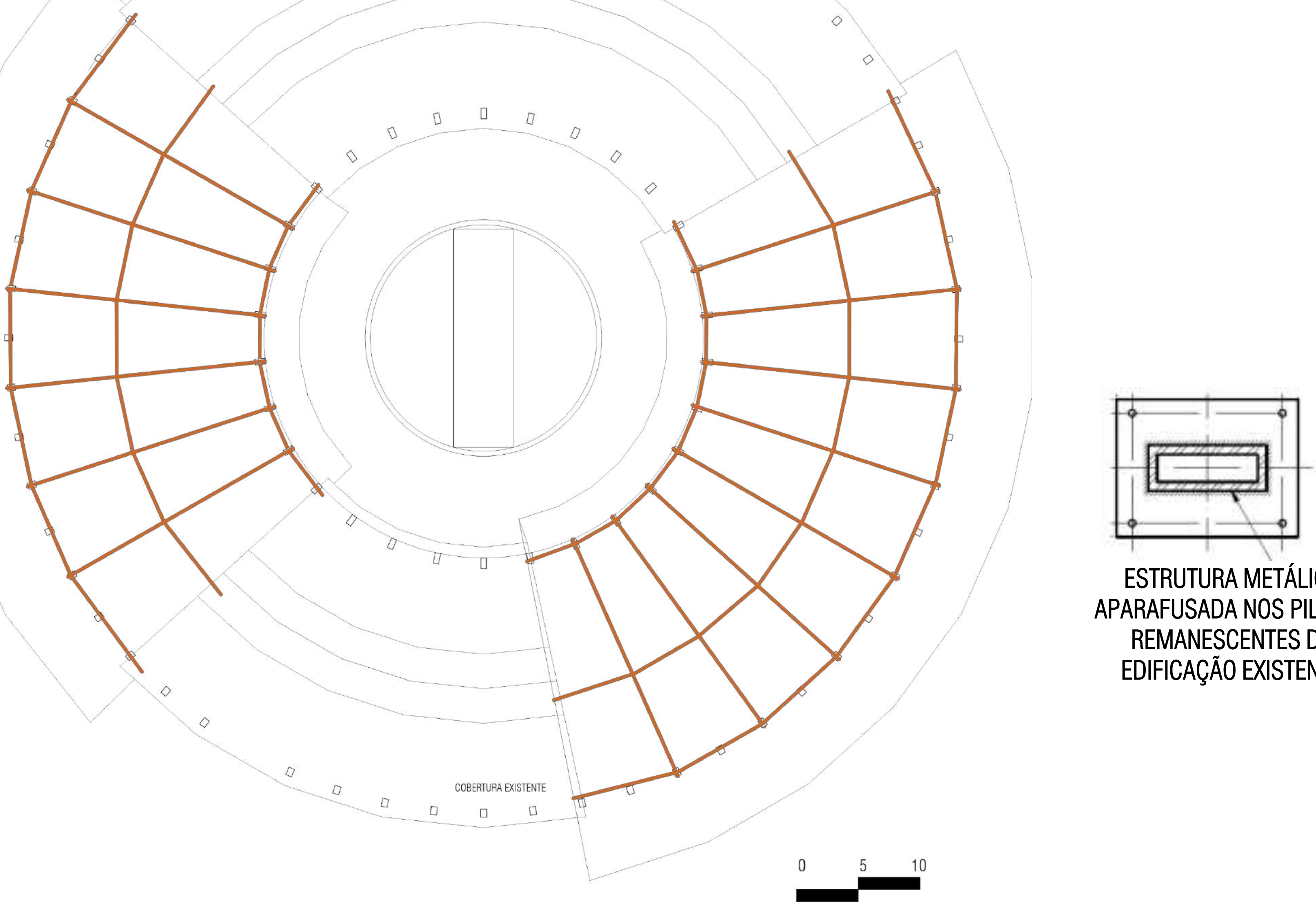

ESTRUTURA METÁLICA APARAFUSADA NOS PILARES

REMANESCENTES DA EDIFICAÇÃO EXISTENTE 

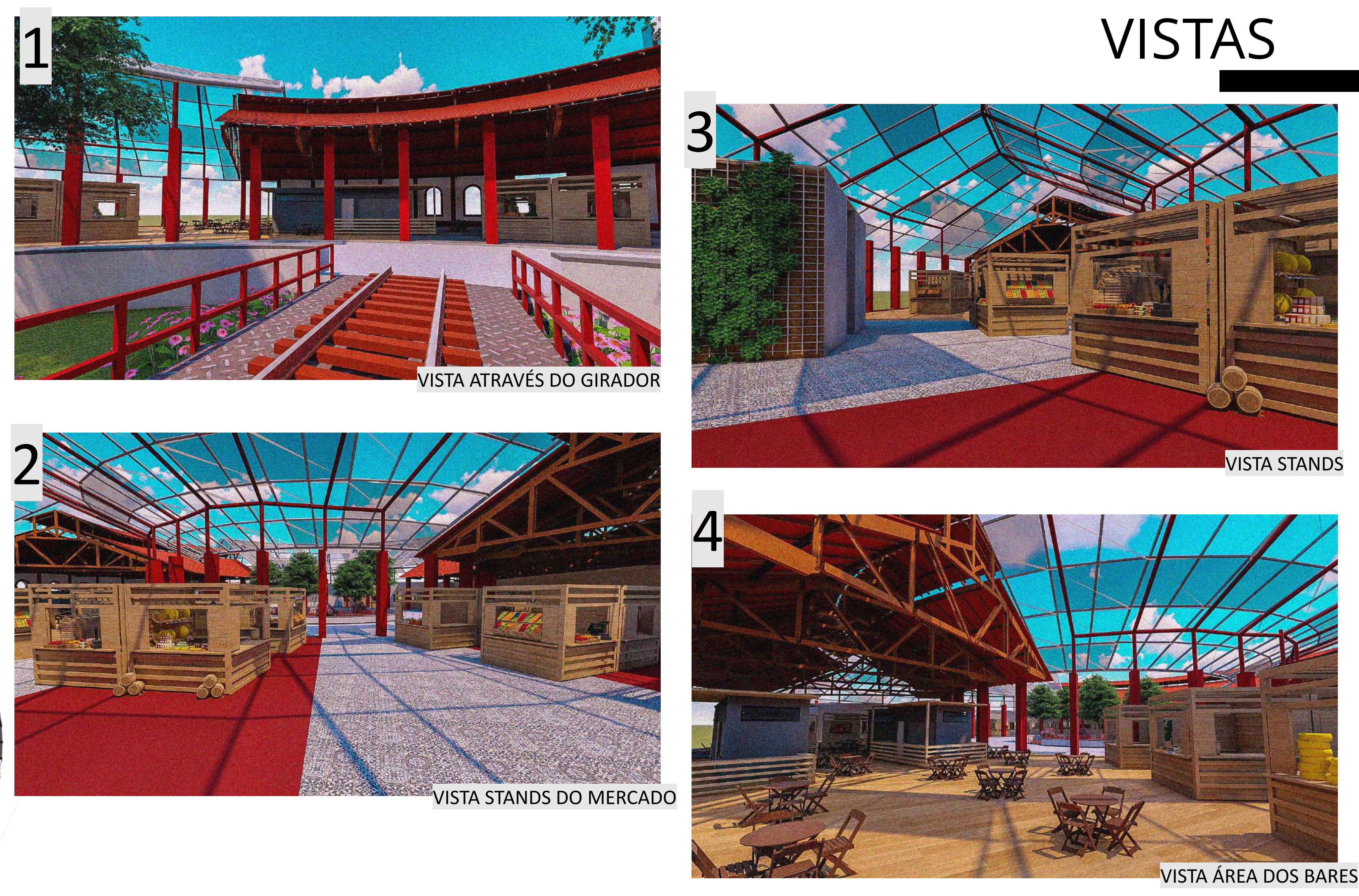
MEMORIAL

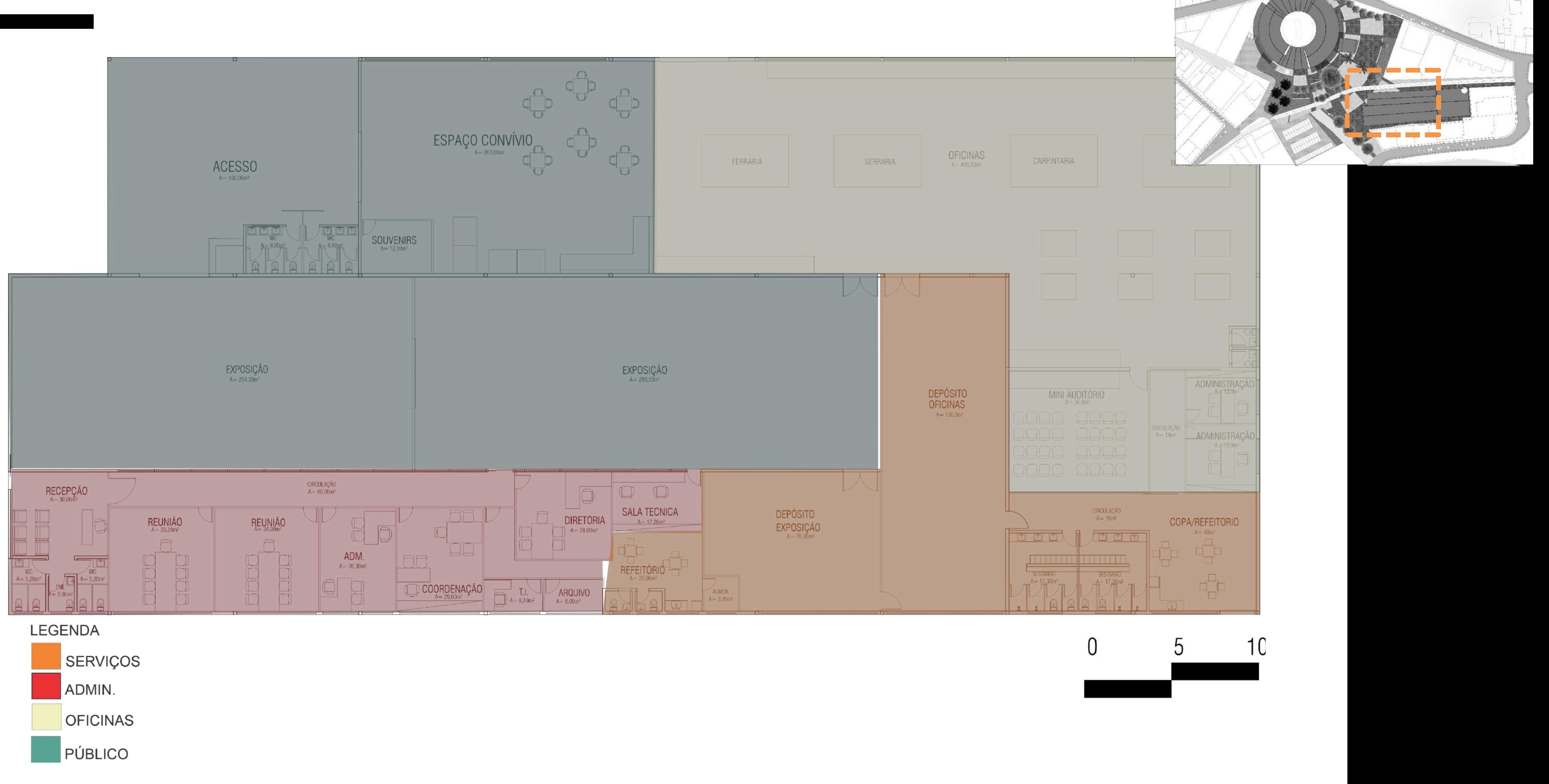


MEMORIAL

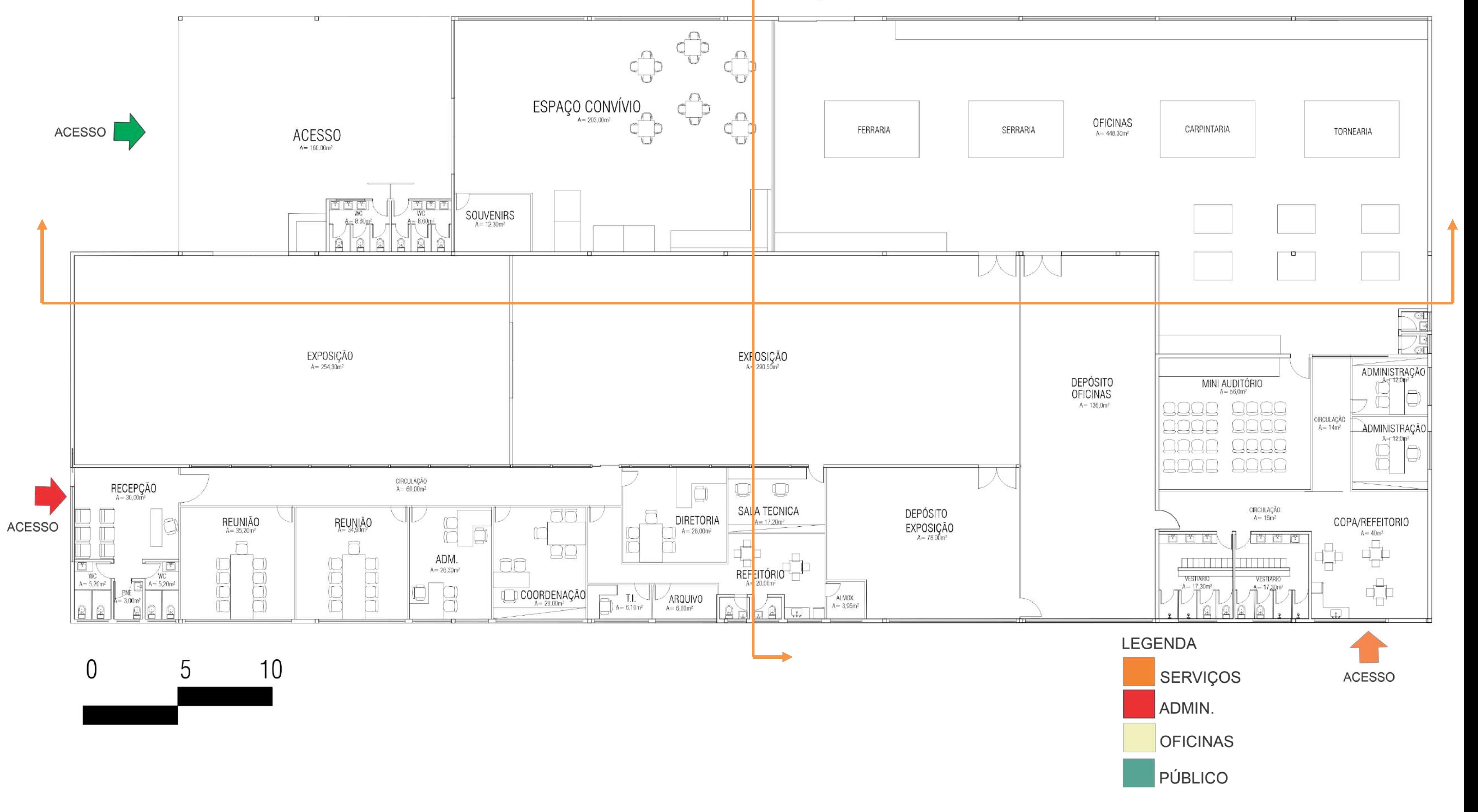


CORTES

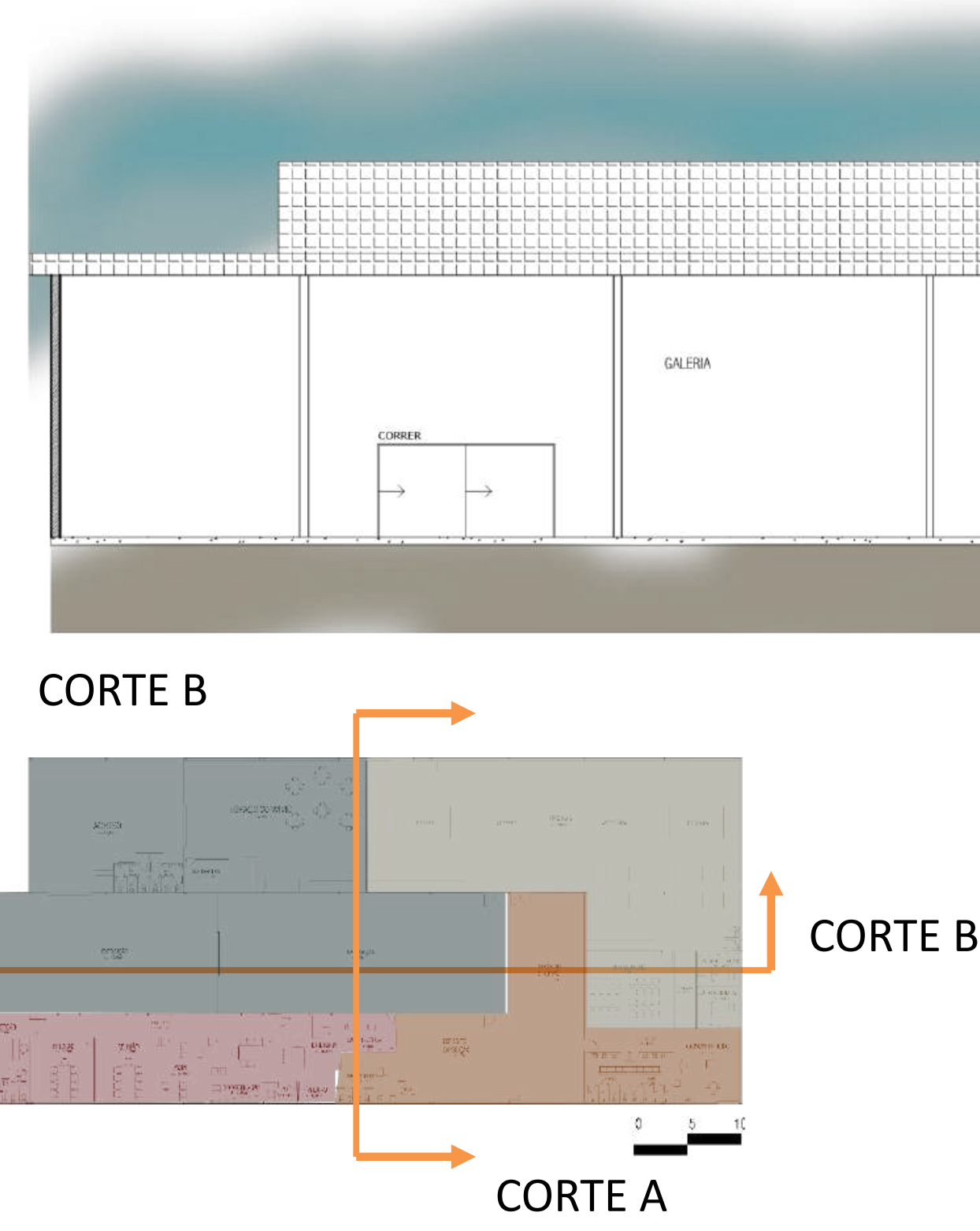




\section{FACHADAS}

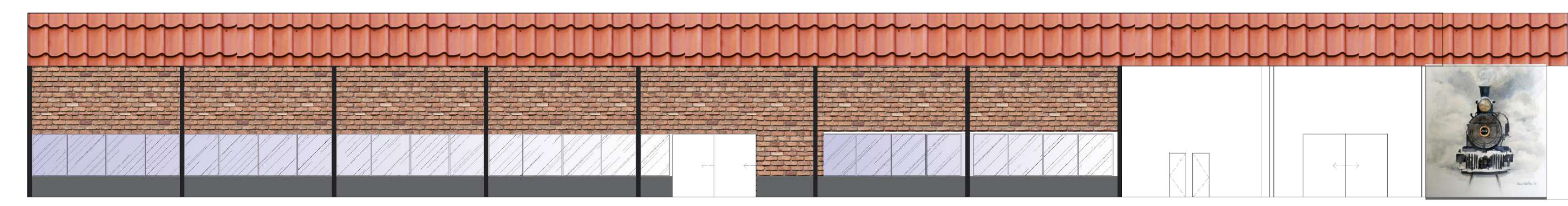

VISTA A

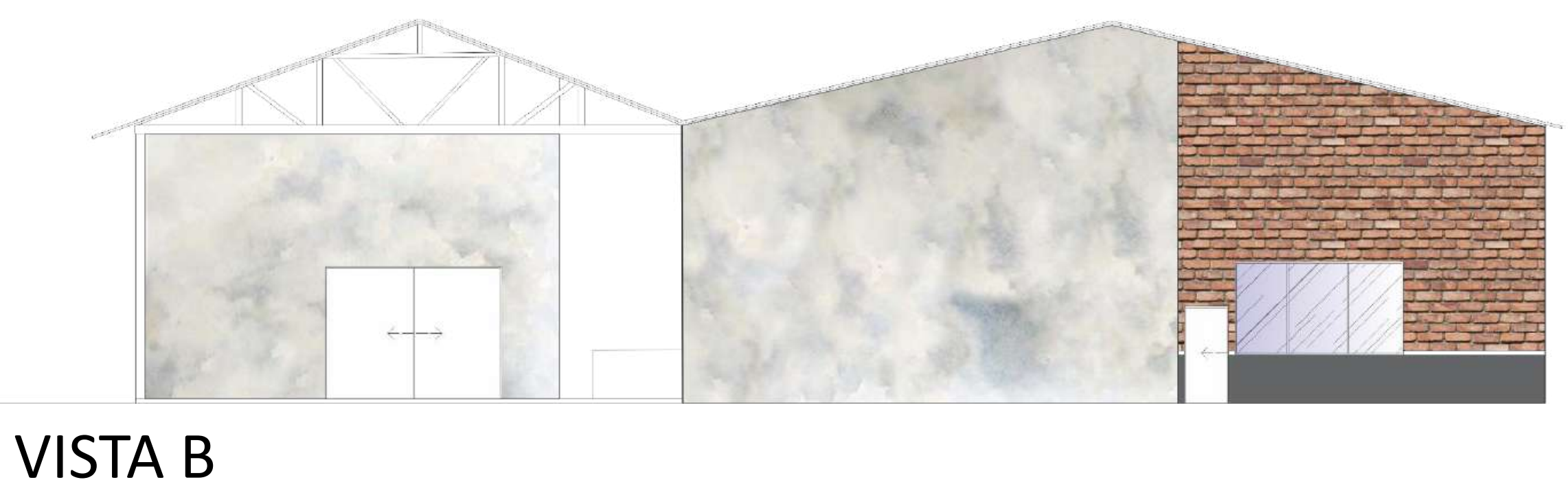

B

A 


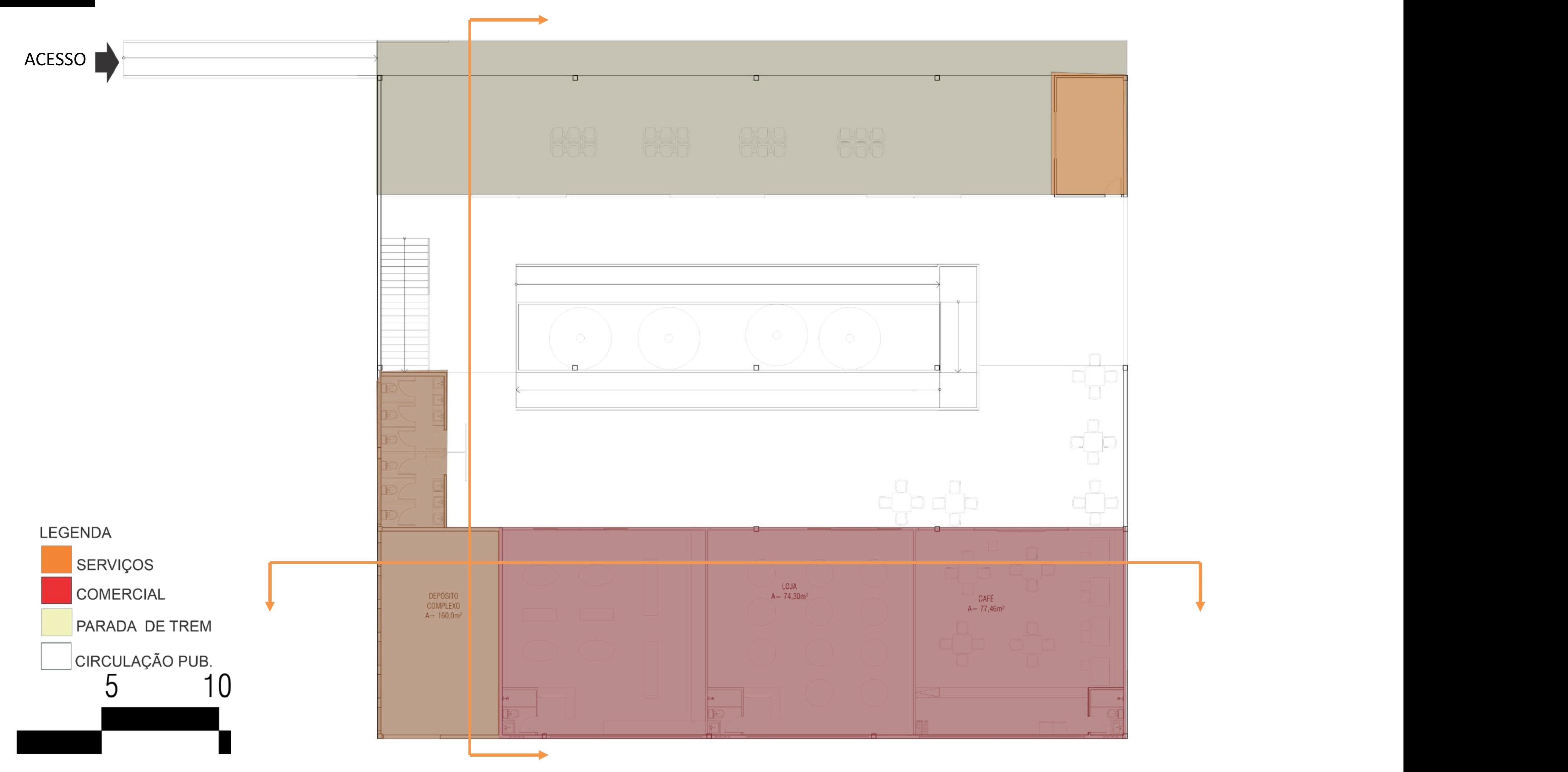


PARADA DE TREM
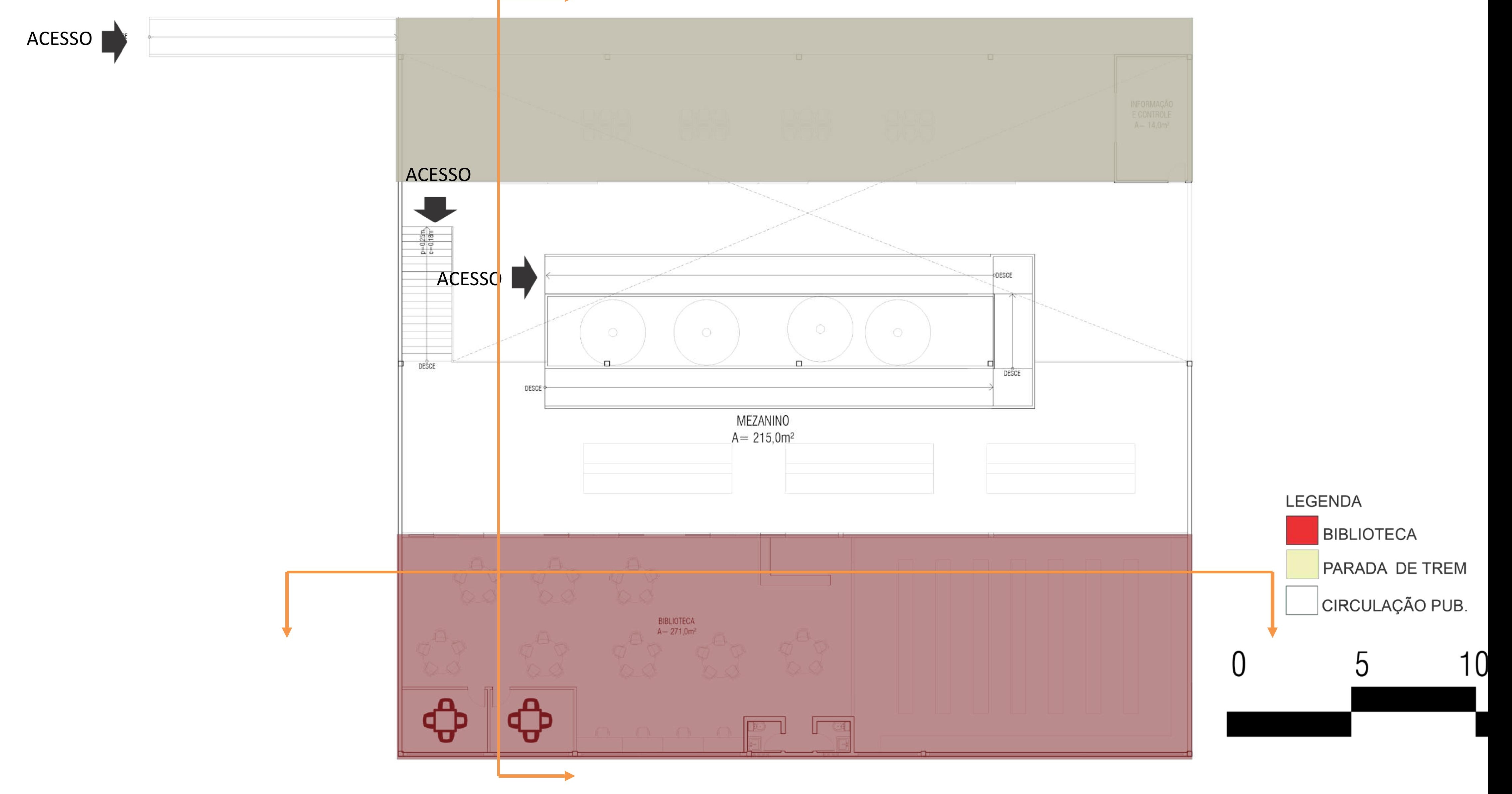


\section{CORTES}

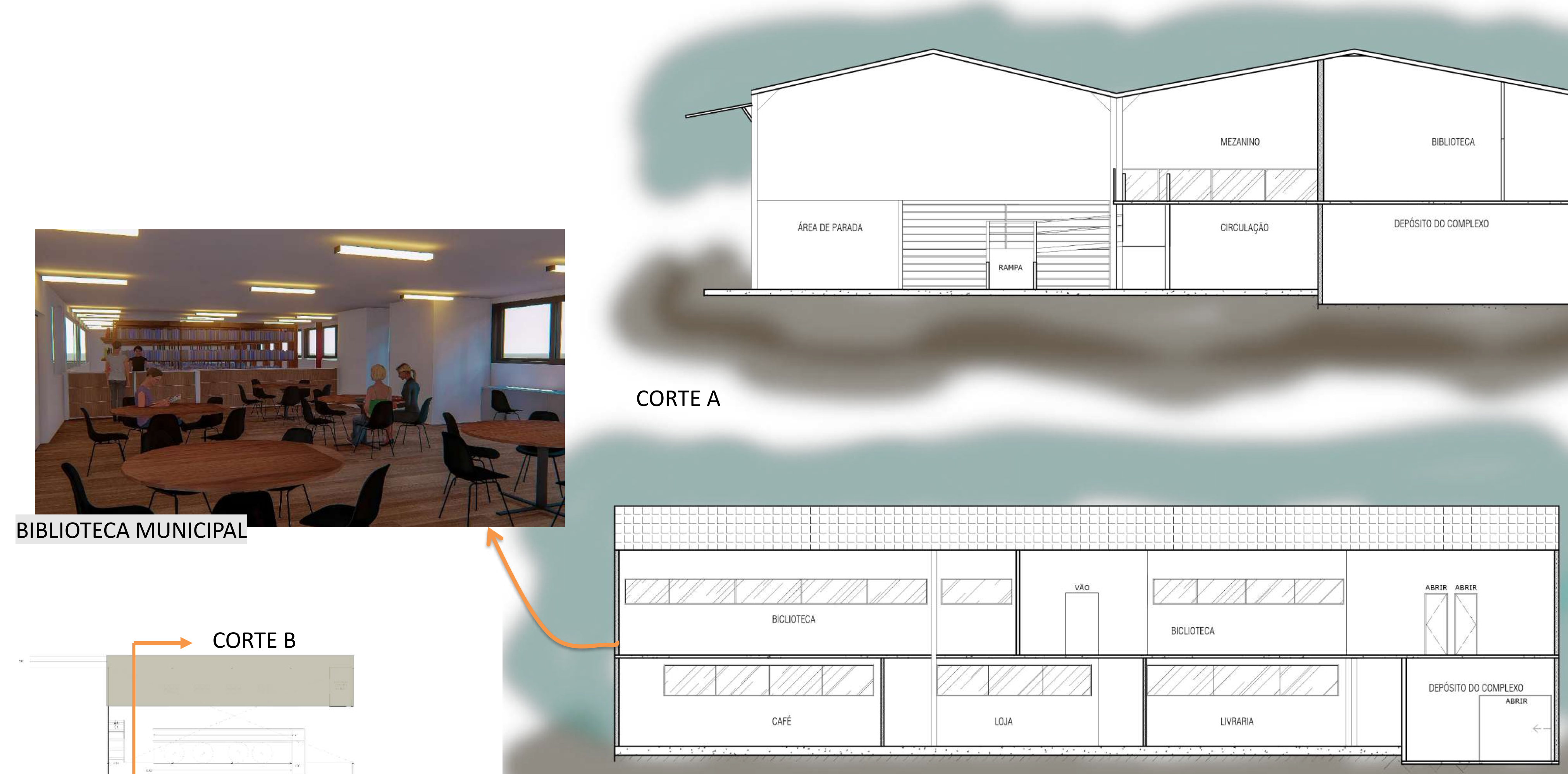


FACHADAS

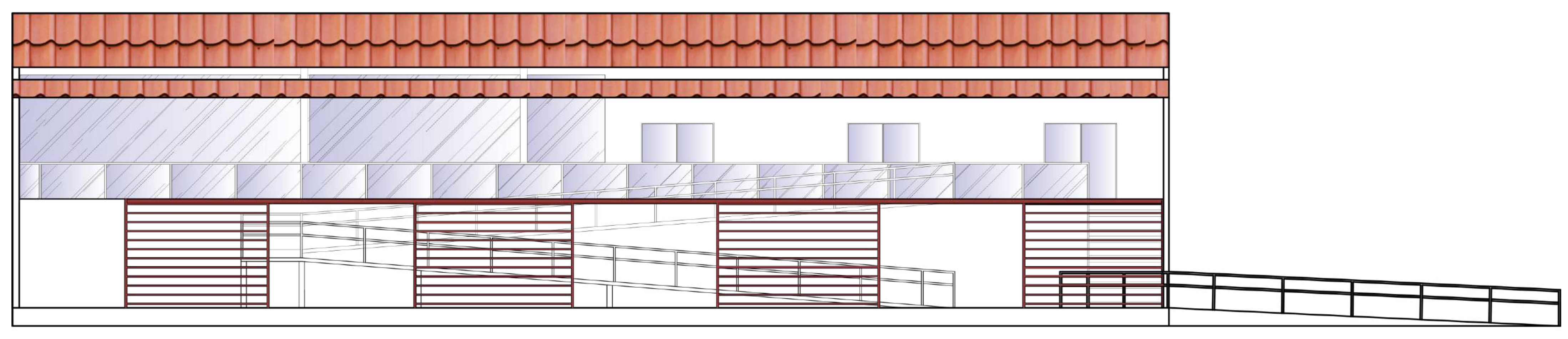

VISTA A

A

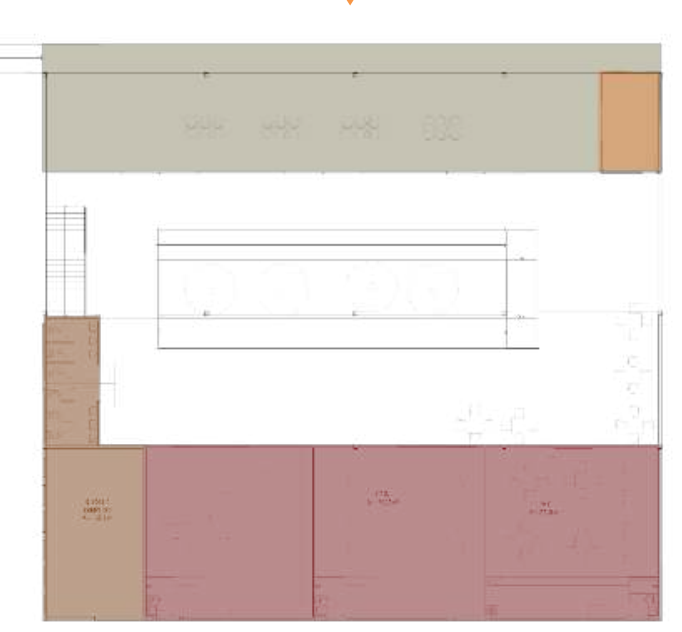



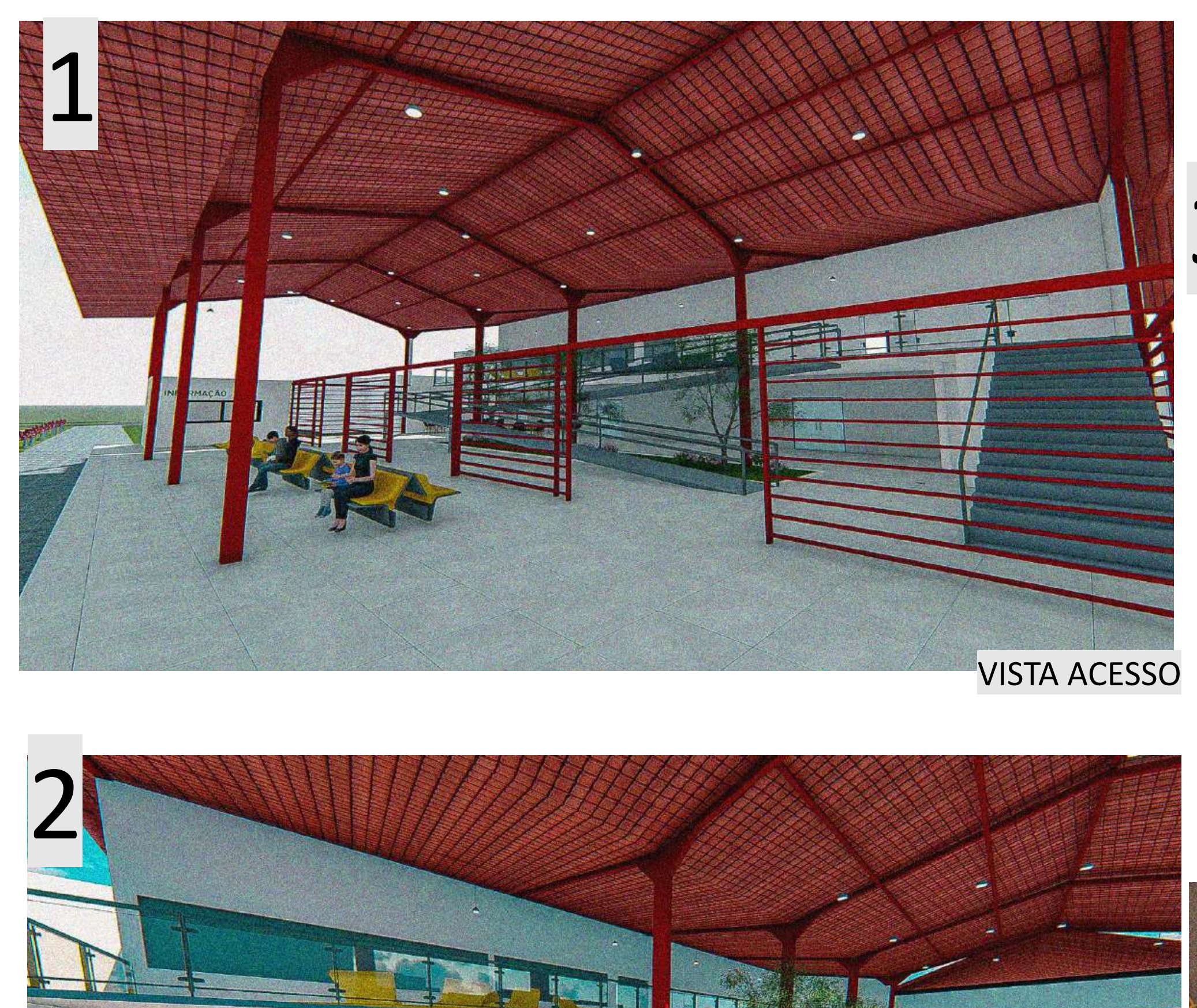

VISTA RAMPA

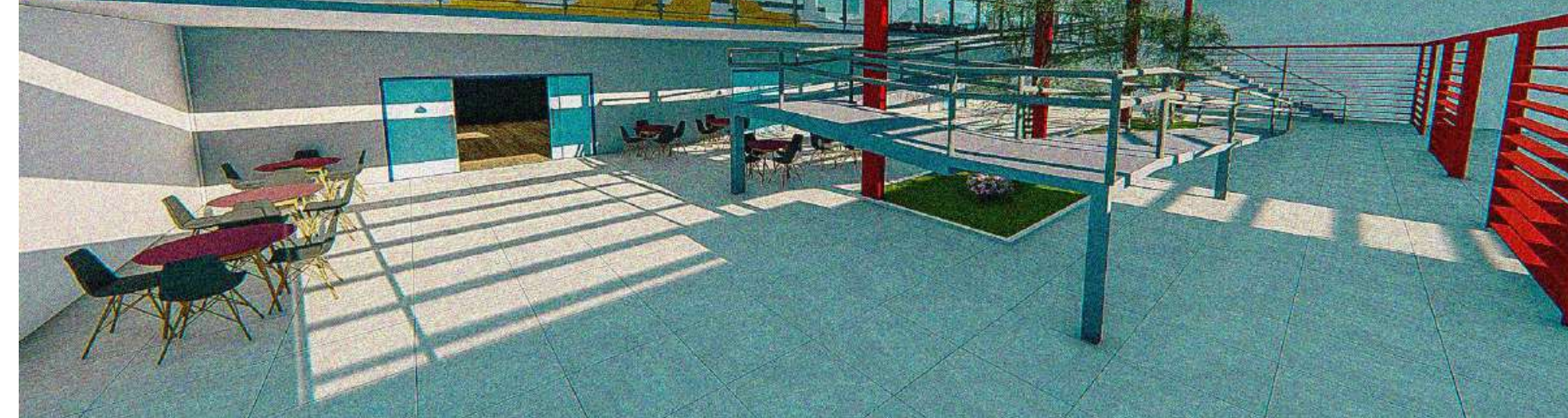




\section{ESTRATÉGIAS SUSTENTÁVEIS}

Restauro de edificações existentes

Sistema de captação de água pluvial a serem usadas para regar jardins, limpezas externas

Uso de materiais drenantes no solo

Utilização de vidros para aproveitamento de iluminação natural

Utilização da placas fotovoltaicas

Ventilação natural

Ventilação cruzada mercado municipal e parada de trens 


\section{O CONJUNTO}

然

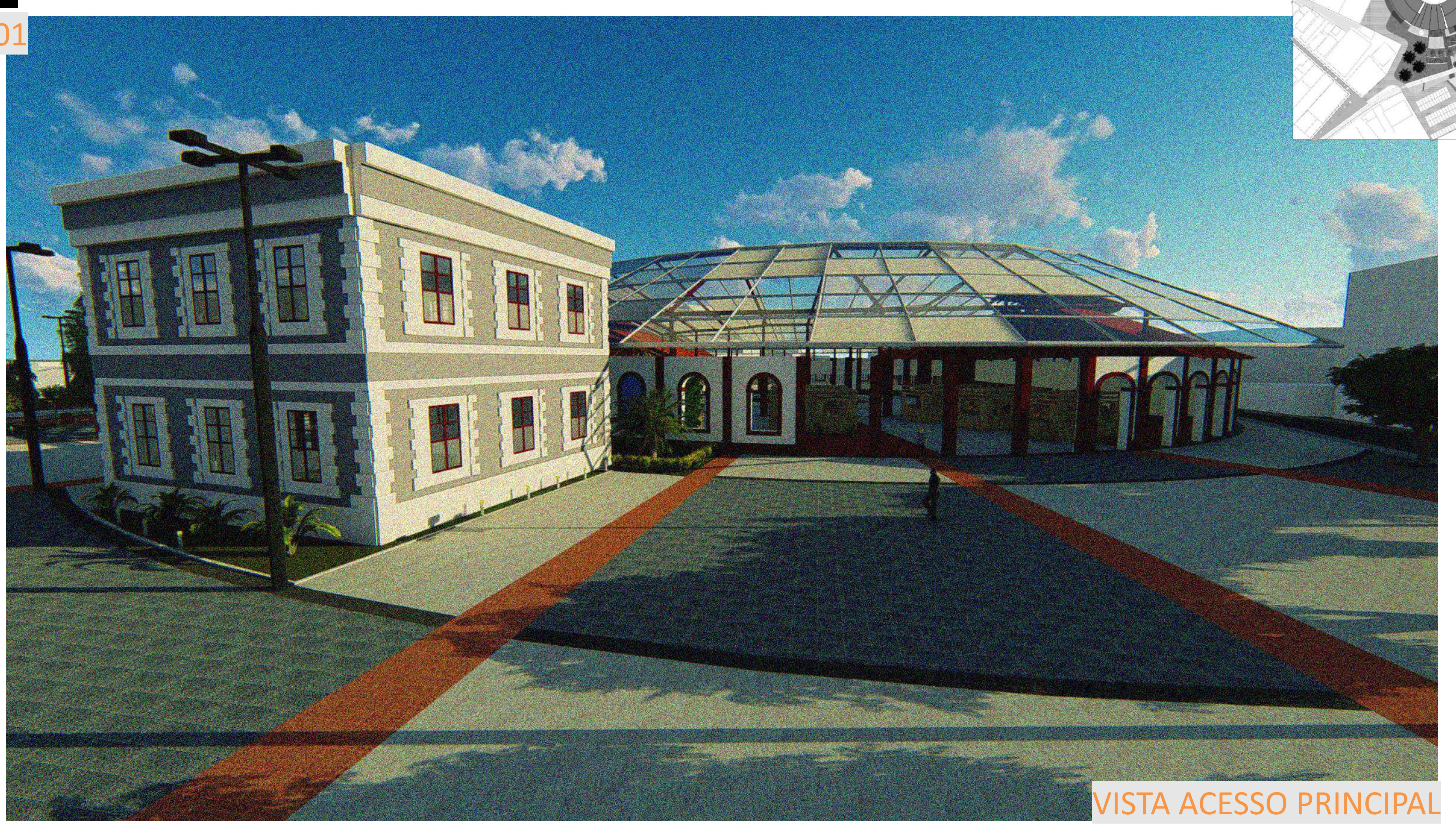




\section{O CONJUNTO}

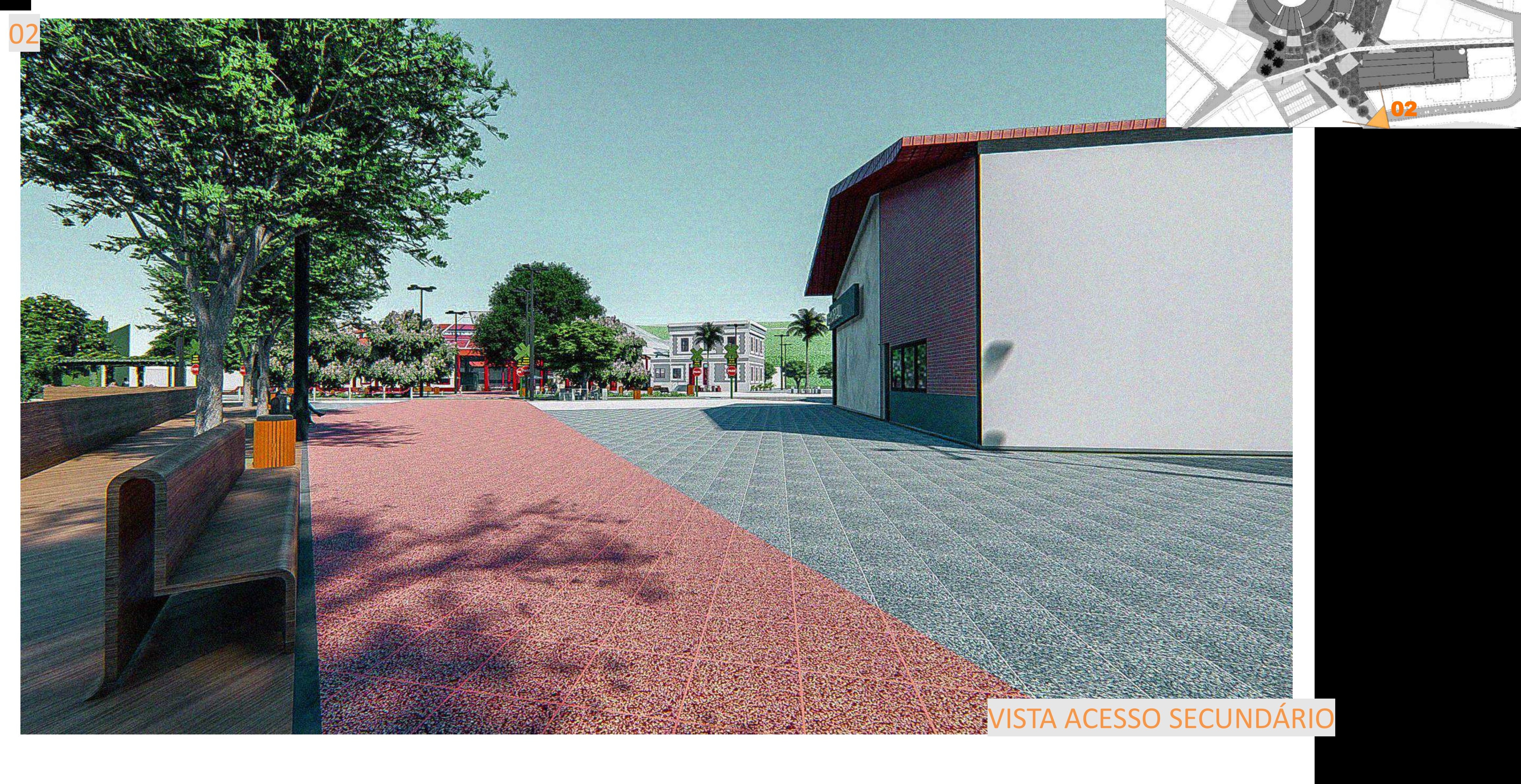




\section{O CONJUNTO}

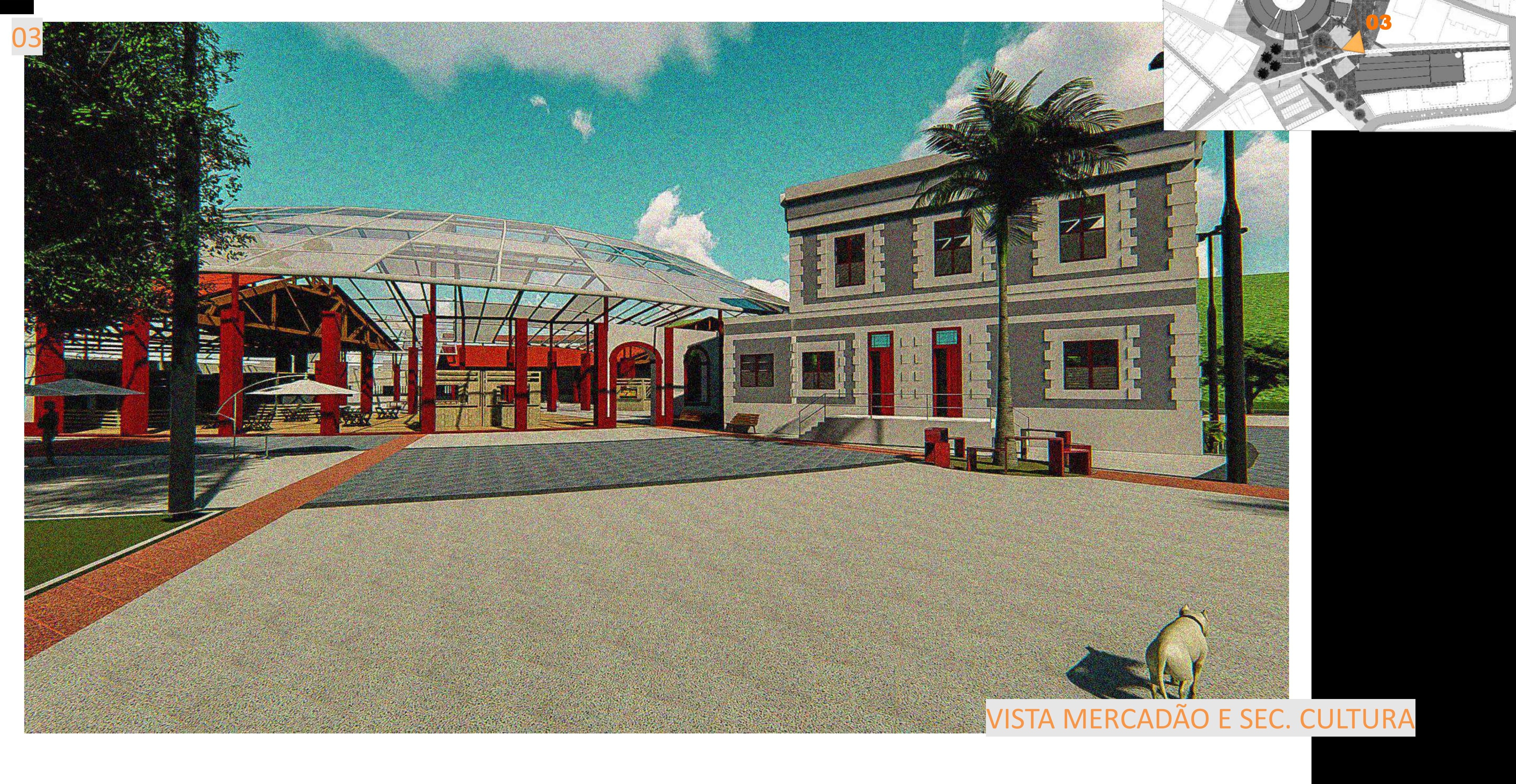




\section{O CONJUNTO}

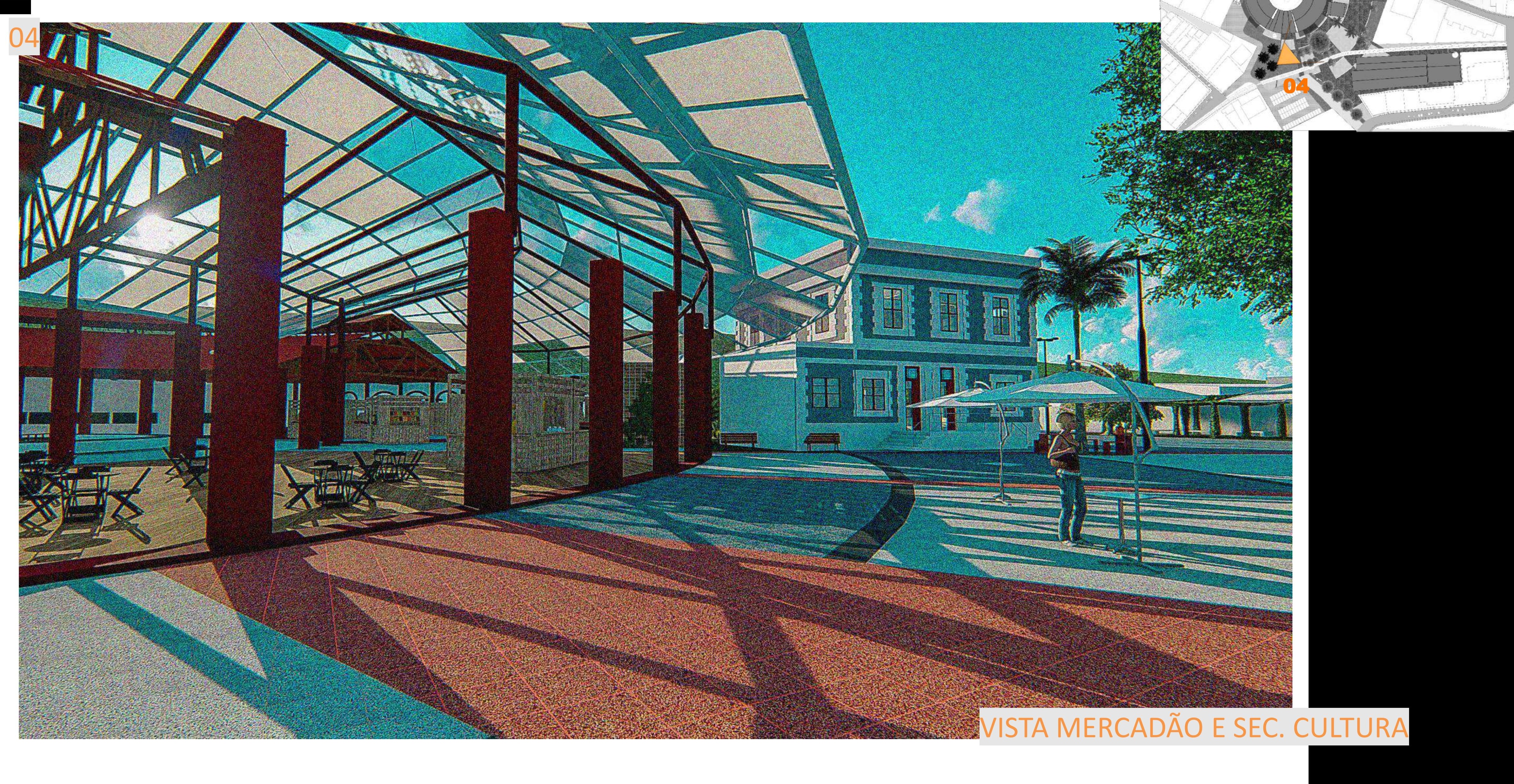




\section{O CONJUNTO}

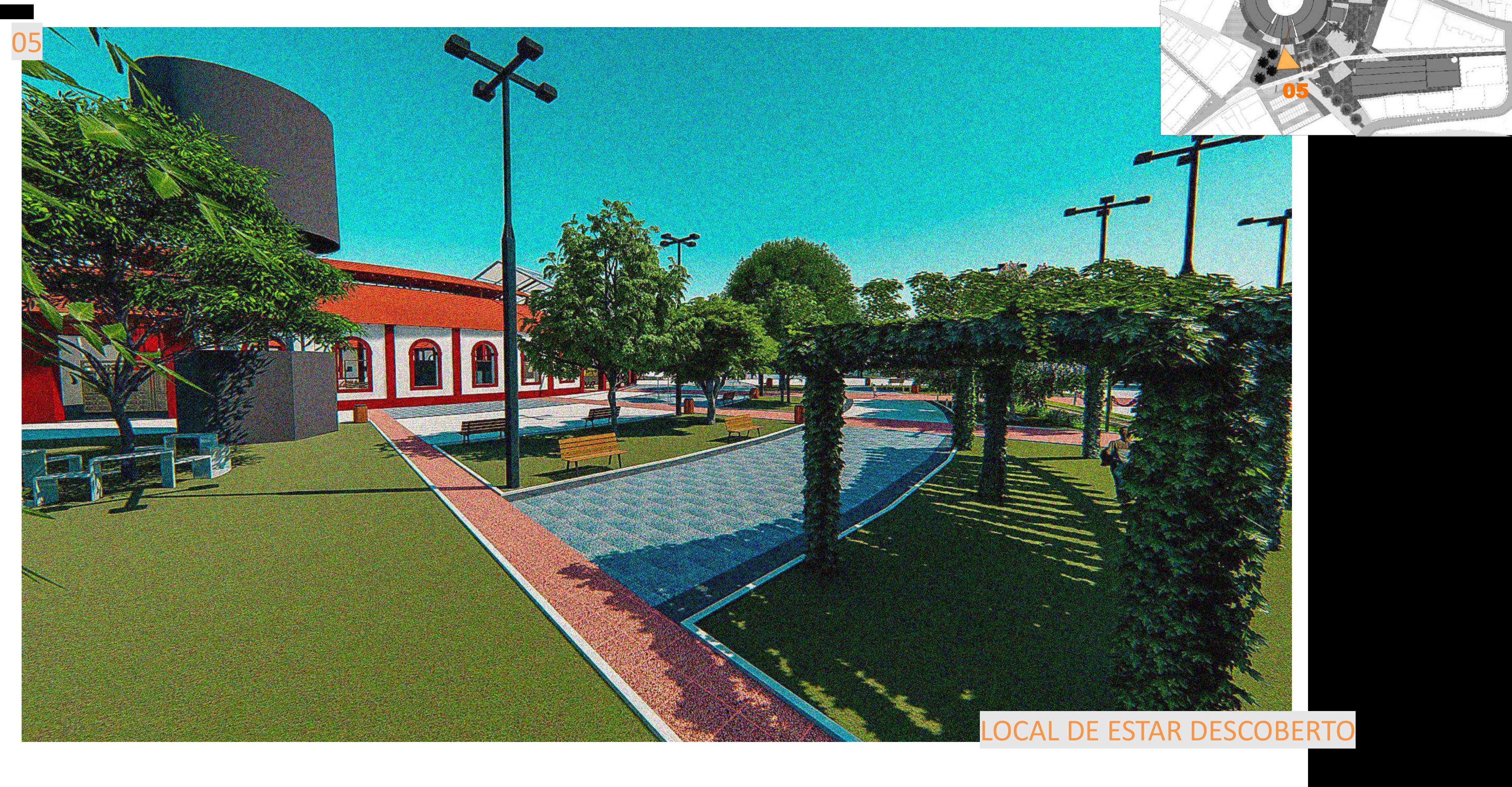




\section{O CONJUNTO}

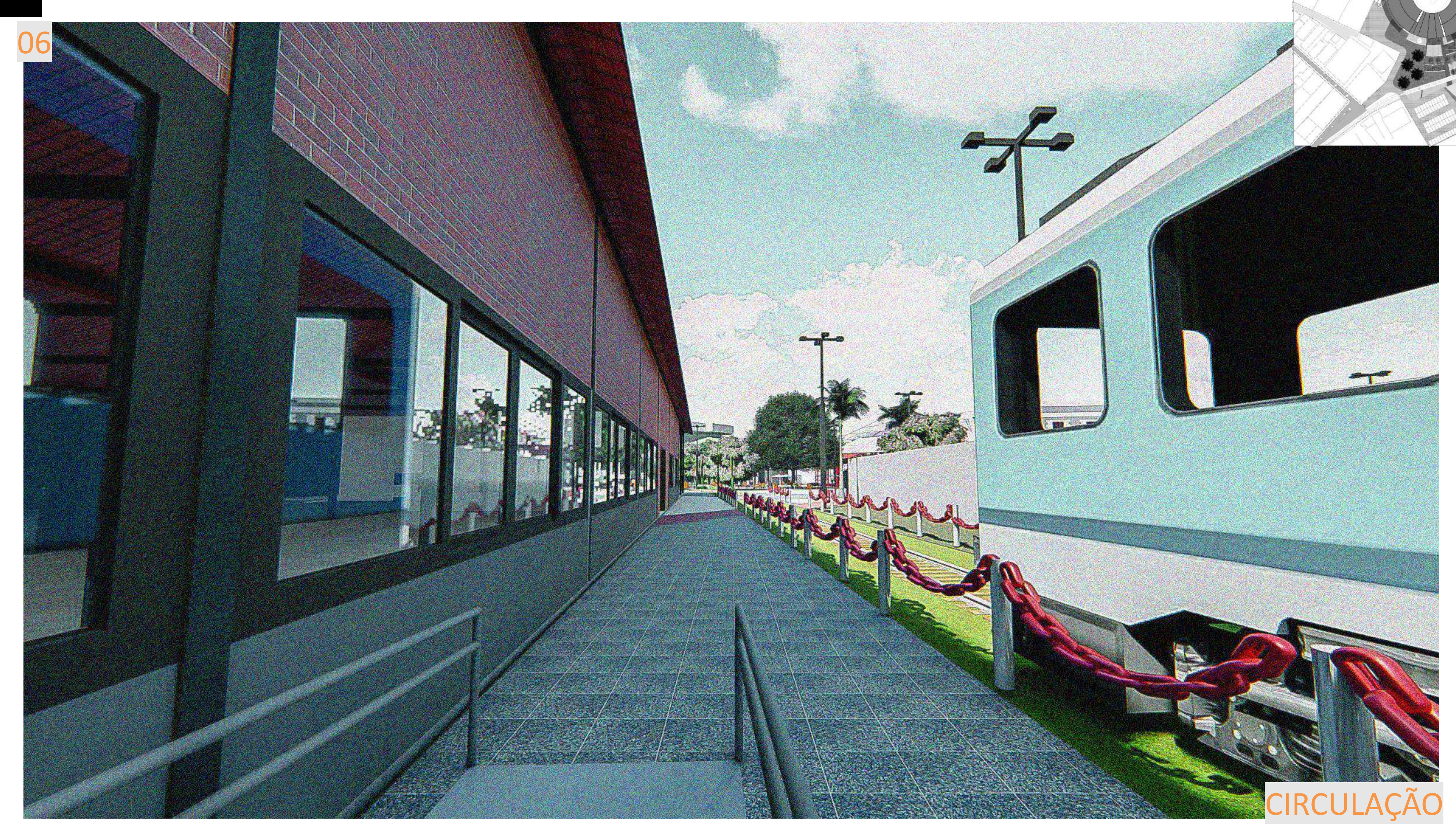




\section{O CONJUNTO}

07
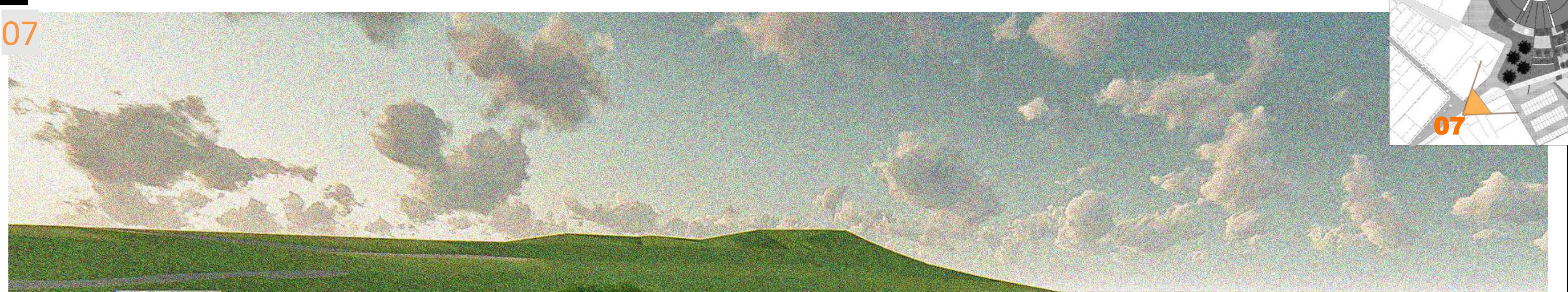

anile

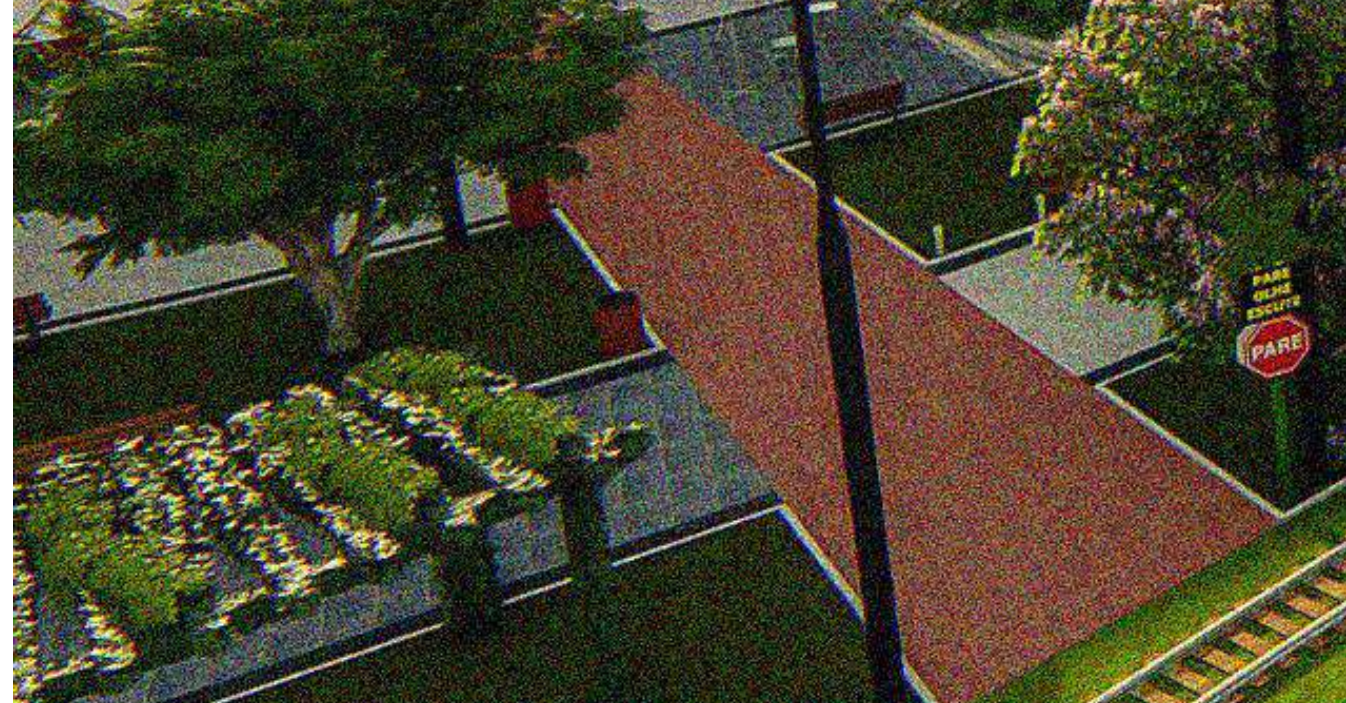




\section{O CONJUNTO}

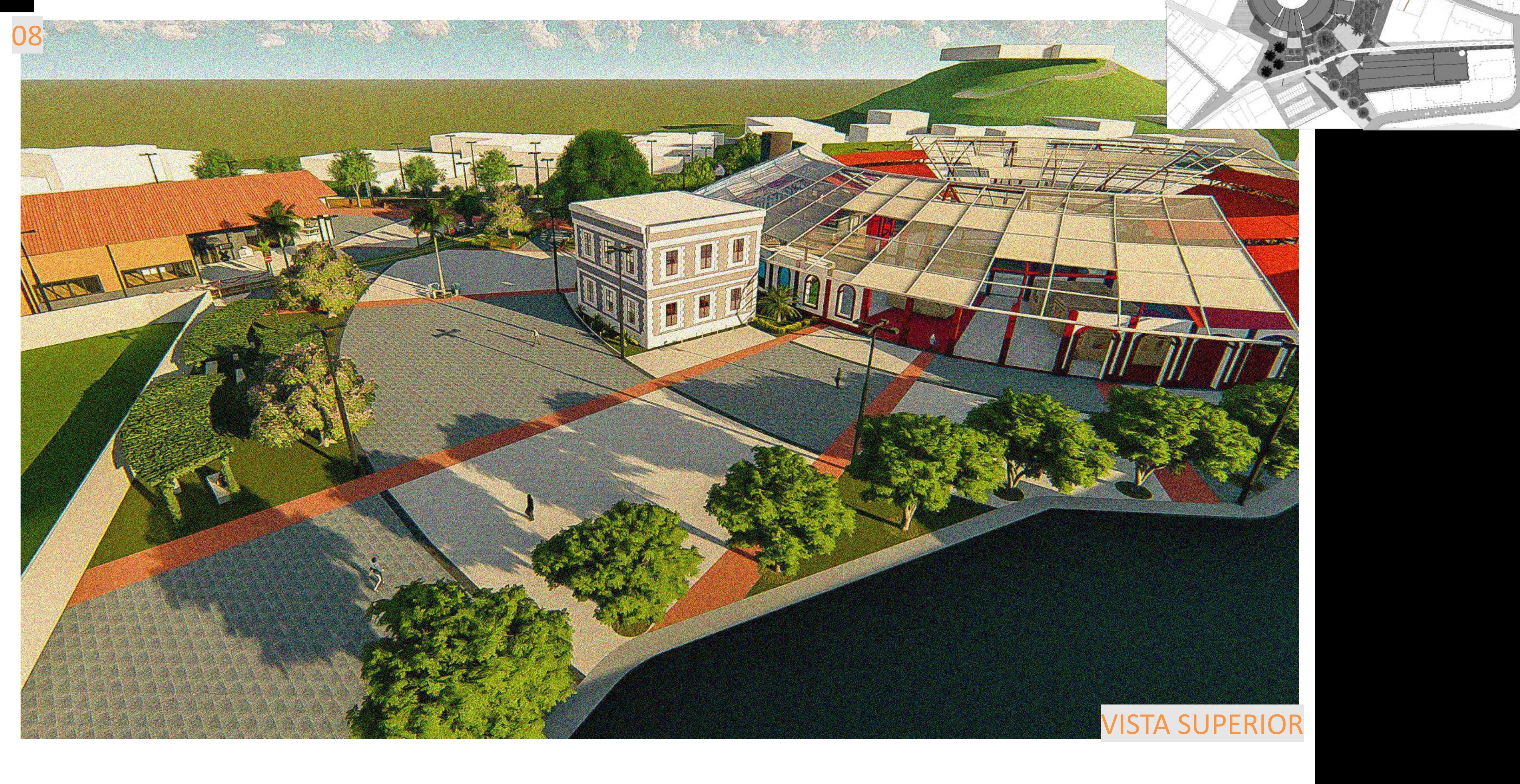

